\title{
Tectonic evolution of southern Baffin Bay and Davis Strait: Results from a seismic refraction transect between Canada and Greenland
}

\author{
Thomas Funck, ${ }^{1}$ Karsten Gohl, ${ }^{2}$ Volkmar Damm, ${ }^{3}$ and Ingo Heyde ${ }^{3}$ \\ Received 19 December 2011; revised 2 March 2012; accepted 8 March 2012; published 26 April 2012.
}

[1] Wide-angle reflection/refraction seismic data were acquired on a 450-km-long transect in southern Baffin Bay extending from Baffin Island to Greenland. Dense air gun shots were recorded on 22 ocean bottom seismometers. A $P$ wave velocity model was developed from forward and inverse modeling of the observed travel times.

Beneath the Baffin Island shelf, a three-layered continental crust is observed with velocities of 5.5 to $6.9 \mathrm{~km} / \mathrm{s}$. Typical for transform margins, there is a sharp transition between continental and oceanic crust. Off Baffin Island, 7-km-thick oceanic crust is interpreted to lie in a major transform fault identified on the gravity map. Beneath the deep Baffin Bay basin, 9-km-thick oceanic crust is encountered but thins to $6 \mathrm{~km}$ within an assumed fracture zone. The thicker than normal oceanic crust indicates an ample magma supply, possibly related to melt extracted from a mantle plume. Seaward of the Greenland continental crust, $20-\mathrm{km}$-thick igneous crust $(6.3$ to $7.3 \mathrm{~km} / \mathrm{s})$ is encountered in a $25-\mathrm{km}$-wide zone interpreted as a leaky transform fault that can be correlated southward through Davis Strait. The igneous crust is bounded by a $20-\mathrm{km}$ wide basin to the west, underlain by 4-km-thick crust of unknown affinity. This structure is probably associated with transform movements. A high-velocity lower crustal layer $(7.1 \mathrm{~km} / \mathrm{s})$ of $8 \mathrm{~km}$ thickness is indicated beneath the Greenland crust and can be correlated into the adjacent thick igneous crust. Both the thick igneous and Greenland crust are covered by up to $4 \mathrm{~km}$ of Paleogene volcanics $(5.2$ to $5.7 \mathrm{~km} / \mathrm{s})$.

Citation: Funck, T., K. Gohl, V. Damm, and I. Heyde (2012), Tectonic evolution of southern Baffin Bay and Davis Strait: Results from a seismic refraction transect between Canada and Greenland, J. Geophys. Res., 117, B04107, doi:10.1029/2011JB009110.

\section{Introduction}

[2] The separation between Greenland and Canada has remained largely unsolved because of an insufficient understanding of the crustal nature in Baffin Bay and Davis Strait and the tectonic relationship of both areas to the Labrador Sea. In order to address this problem, the German research vessel Maria S. Merian carried out a geophysical survey in Davis Strait and southern Baffin Bay (Figures 1 and 2). The expedition was a component of the lead project "Plate Tectonics and Polar Gateways in the Earth System (PLATES and GATES)" of the International Polar Year (IPY 2007/08). The overall objective of the cruise was the tectonic and sedimentary reconstruction of the opening of Davis Strait and southern Baffin Bay. The study of this

\footnotetext{
${ }^{1}$ Geological Survey of Denmark and Greenland, Copenhagen, Denmark. ${ }^{2}$ Alfred Wegener Institute for Polar and Marine Research, Bremerhaven, Germany.

${ }^{3}$ Federal Institute for Geosciences and Natural Resources, Hanover, Germany.
}

Published in 2012 by the American Geophysical Union. paper covers the tectonic development and architecture of the southern Baffin Bay and its transition to Davis Strait, while the spreading history of southern and central Baffin Bay is described in Suckro et al. [2012].

[3] No modern seismic refraction data are available for southern Baffin Bay. Older sonobuoy profiles are interpreted to indicate the presence of oceanic crust [Keen and Barrett, 1972]. However, the obtained velocity functions show a substantial scatter and are not always compatible with average oceanic crust [White et al., 1992]. Furthermore, no linear magnetic anomalies typical for seafloor spreading could be identified in Baffin Bay yet [Chalmers and Pulvertaft, 2001]. The new data set will allow the nature of the crust in southern Baffin Bay to be determined, whether it consists of oceanic crust or of unroofed and partially serpentinized mantle as suggested for northern Baffin Bay [Reid and Jackson, 1997]. Despite the lack of unequivocal evidence for oceanic crust in Baffin Bay, a prominent gravity low in the center of the bay is interpreted as the location of the extinct spreading axis [Whittaker et al., 1997]. Other north-south striking anomalies are interpreted as the expression of transform faults [Whittaker et al., 1997; Chalmers and Pulvertaft, 2001]. The seismic refraction 


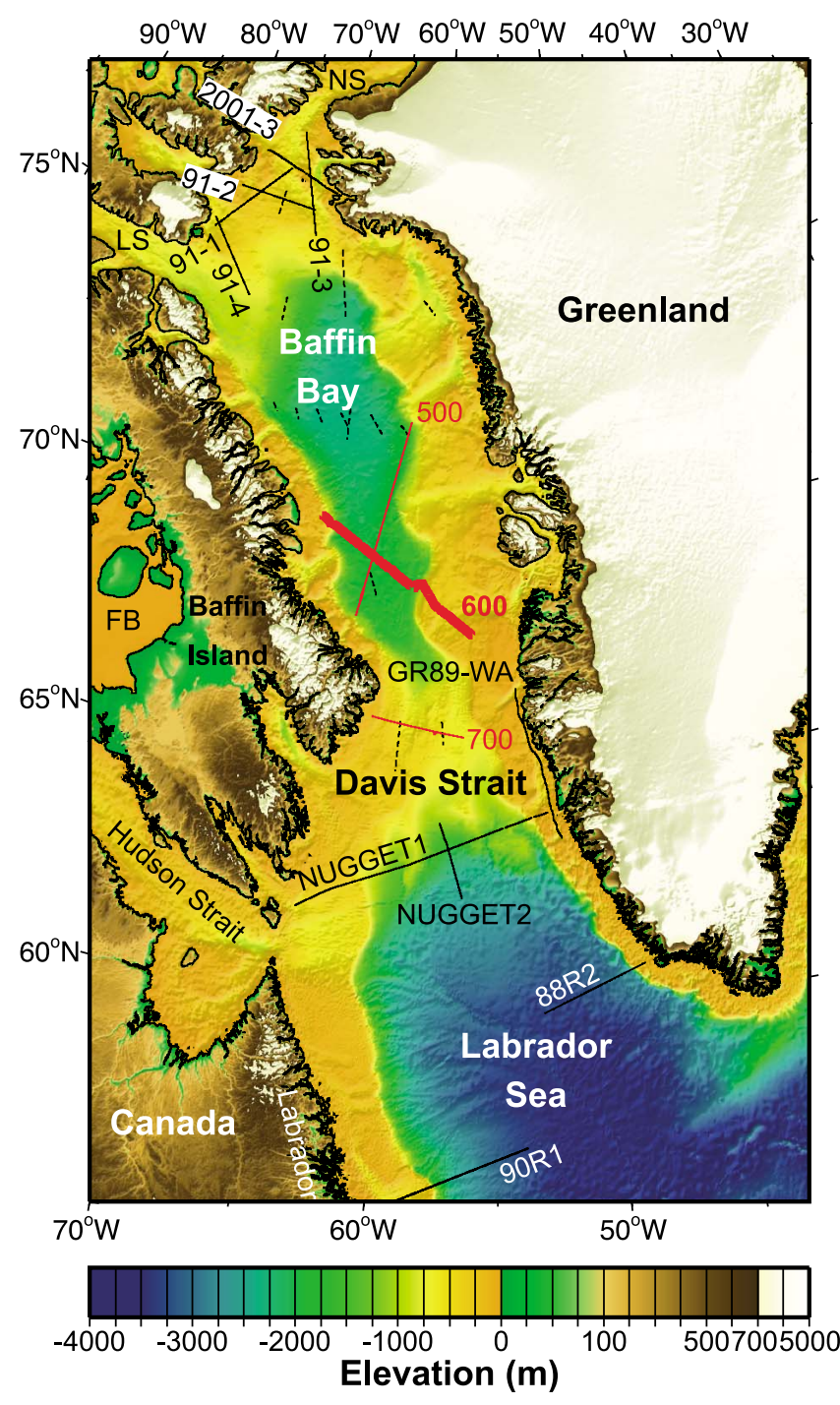

Figure 1. Bathymetric map Baffin Bay and Labrador Sea. Data source: General Bathymetric Chart of the Oceans (GEBCO) 08 grid (http://www.gebco.net). Seismic refraction lines of the Maria $S$. Merian cruise MSM09/3 are shown in red [Gohl et al., 2009]. Solid lines indicate published seismic refraction lines in Baffin Bay and Davis Strait as well as selected profiles in the Labrador Sea (lines 91-1 and 91-3 [Jackson and Reid, 1994]; lines 91-2 and 91-4 [Reid and Jackson, 1997]; line 2001-3 [Funck et al., 2006]; line GR89-WA [Gohl and Smithson, 1993]; line NUGGET 1 [Funck et al., 2007]; line NUGGET 2 [Gerlings et al., 2009]; line 88R2 [Chian and Louden, 1994]; line 90R1[ Chian et al., 1995b]). Dashed lines mark the location of sonobuoy lines [Keen and Barrett, 1972; Srivastava et al., 1982]. Abbreviations are FB, Foxe Basin; LS, Lancaster Sound; NS, Nares Strait.

component of the project was designed to map the crustal character and thickness in Baffin Bay, and to check for the seismic expression of the gravity lows. This will set the stage for the discussion of the tectonic development of the area.

[4] Paleogene volcanism in the Davis Strait and southern Baffin Bay is associated with a mantle plume [Storey et al., 1998]. The seismic refraction data will provide information on the distribution and volume of this volcanism, both near the surface and as underplated layers at deep-crustal levels. This will also allow the interaction between the plume and the transform-rifted margin in the Davis Strait [Funck et al., 2007] to be investigated.

\section{Geological Setting}

\subsection{General Setting}

[5] Davis Strait is a bathymetric high between Baffin Island to the west and Greenland to the east that separates Labrador Sea from Baffin Bay (Figure 1). The oldest undisputed seafloor spreading magnetic anomaly in the Labrador Sea is magnetic chron 27n (62.0-61.7 Ma using the time scale of Gradstein et al. [2005]) [Chalmers and Laursen, 1995]. Other authors suggest that seafloor spreading started during magnetic chron 33 (84-73.6 Ma) [Roest and Srivastava, 1989] or between magnetic chrons 29 and 31 (71.0-64.4 Ma) [Chian et al., 1995a]. A reorientation of the spreading axis took place during magnetic chron $24 \mathrm{r}$ $(56.7-53.8 \mathrm{Ma})$, at the same time that seafloor spreading initiated between Greenland and Europe. Spreading in the Labrador Sea ceased by magnetic chron 13 (34.8-33.3 Ma) [Srivastava, 1978]. The continental stretching and rifting in the Labrador Sea and Davis Strait occurred over an extended period of time as indicated by dyke swarms in West Greenland. Based on the ages of these dykes, Larsen et al. [2009] identified several phases of tectonomagmatic activity: initial stretching from the Late Triassic to Late Jurassic (223 to $150 \mathrm{Ma}$ ), stretching and thinning in the Late Jurassic (150 Ma), further stretching and thinning in the Early Cretaceous (140 to $133 \mathrm{Ma}$ ) followed by Paleogene thinning and break-up (63 to $50 \mathrm{Ma}$ ).

[6] Baffin Bay is the northwest extension of the Labrador Sea spreading system. The transform margin in Davis Strait that links these two areas is characterized by the Ungava transform fault, a name that was first introduced by Kerr [1967]. Later, the term Ungava fault zone (UFZ) became more commonly used (Figure 2). The position of the UFZ is taken to be along the SE side of a line of positive gravity anomalies. Davis Strait and the northern Labrador Sea are bounded by volcanic margins [Keen et al., 2012; Gerlings et al., 2009; Funck et al., 2007; Chalmers, 1997]. Onshore, Palaeogene volcanics crop out on either side of the strait in a short narrow belt near Cape Dyer on Baffin Island and in a wider zone in the Disko-Svartenhuk area of West Greenland (Figure 2). Storey et al. [1998] identified two main pulses of volcanism in West Greenland: one between 60.7 and 59.4 Ma and one between 54.8 and $53.6 \mathrm{Ma}$. The first pulse is probably related to the arrival of the Iceland plume beneath Greenland [Lawver and Müller, 1994; Storey et al., 1998]. However, the assumed plume position at that time is based on models and not on direct observations. Larsen and Saunders [1998] explain the almost simultaneous volcanism from 62 to $60 \mathrm{Ma}$ in West Greenland [Storey et al., 1998], East Greenland [Larsen and Saunders, 1998], and on the British Isles [Pearson et al., 1996] by rapid lateral flow of a small plume head that impinged on the continental lithosphere. Continental break-up of East Greenland from NW Europe occurred at $56 \mathrm{Ma}$ [Larsen and Saunders, 1998] and caused a reorientation of the spreading axis in the Labrador Sea [Srivastava, 1978]. Storey et al. [1998] suggested that the 


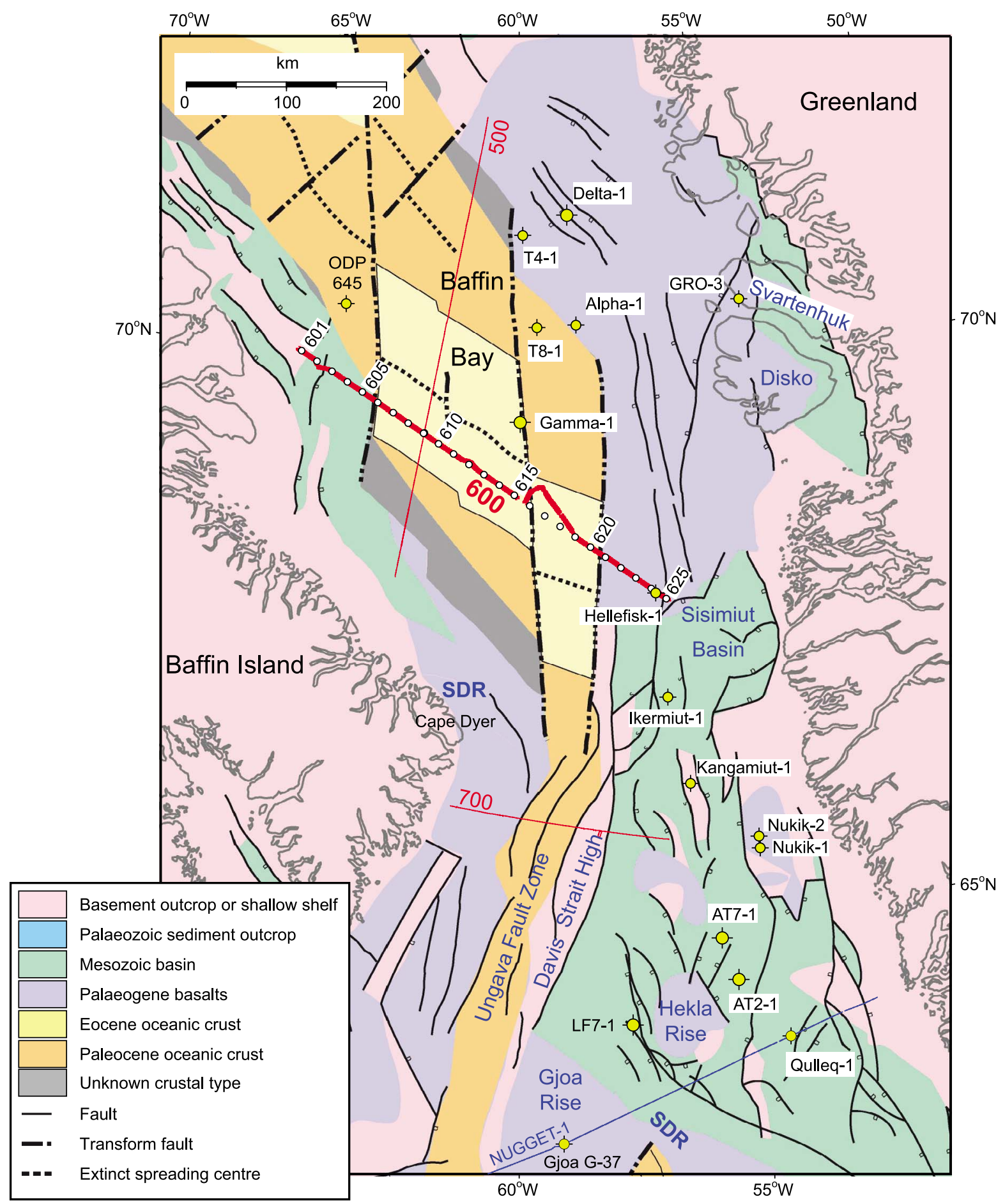

Figure 2. Geologic map of the southern Baffin Bay, the Davis Strait region and the northernmost Labrador Sea [after Chalmers and Oakey, 2007]. Red lines indicate the location of the MSM09/3 seismic refraction lines (AWI20080[500/600/700]) with white circles showing the position of ocean bottom seismometers (OBS) along line 600. The station number of every 5th OBS is labeled. Well locations are indicated by yellow circles. The blue line marks the location of NUGGET line 1 [Funck et al., 2007]. Abbreviation SDR is seaward dipping reflections.

second pulse of volcanism in West Greenland could be related to this reorientation of the spreading axis, during which remnants of the plume could have generated melts along the UFZ. Volcanic layers, lava flows and seaward dipping reflectors (SDR) are mapped in large areas of Davis
Strait [Skaarup et al., 2006; Chalmers and Laursen, 1995; Chalmers, 1997]. In addition, volcanic rocks were drilled in a number of wells (Hekja O-71 and Gjoa G-37 [Klose et al., 1982]; Ralegh N-18 (BASIN database, Geological Survey of Canada, Dartmouth, Nova Scotia, Canada); Hellefisk-1 
and Nukik-2 [Rolle, 1985]). Laser Argon dating of basaltic rocks from the Gjoa well (Figure 2) yielded ages of $59.5 \mathrm{Ma}$ [Williamson et al., 2001], which relates those rock samples to the first pulse of volcanism.

[7] Baffin Bay forms a sedimentary basin that extends from Davis Strait in the south to Nares Strait in the north. The sediment thickness is up to $12 \mathrm{~km}$ in northern Baffin Bay [Reid and Jackson, 1997]. The nature of the crust in Baffin Bay is disputed. Keen et al. [1974] provide evidence that the Baffin Bay crust was created by seafloor spreading, which is supported by velocity models that are compatible with oceanic crust [Keen and Barrett, 1972]. In contrast, Reid and Jackson [1997] interpret their velocity model as evidence for serpentinised mantle in northern Baffin Bay in support for amagmatic continental rifting and separation. Serpentinised mantle is often observed in ocean-continent transition zones of non-volcanic continental margins [e.g., Funck et al., 2003, 2004] or at ultra-slow spreading ridges [Jokat et al., 2003]. Chalmers and Pulvertaft [2001] point out that there are no unequivocal magnetic anomalies in Baffin Bay that can be related to seafloor spreading. Absence of these anomalies could be related to oblique spreading or to a blanketing effect of up to $12 \mathrm{~km}$ of sediments. The position of the extinct spreading axis and of the transform faults in Figure 2 is determined from gravity and magnetic anomaly maps [Chalmers and Pulvertaft, 2001; Chalmers and Oakey, 2007].

\subsection{Previous Geophysical Studies}

[8] The coverage by refraction and regional deep seismic reflection data is variable along the ocean basins west of Greenland. The most detailed picture is available for the Labrador Sea, where a number of refraction profiles define the non-volcanic nature of the conjugate continental margins of Labrador and SW Greenland [e.g., Chian and Louden, 1994; Chian et al., 1995b]. In addition, long regional seismic reflection lines were acquired by the Federal Institute for Geosciences and Natural Resources (BGR), the Geological Survey of Canada (GSC) and LITHOPROBE [e.g., Chalmers and Laursen, 1995; Chian et al., 1995a; Hall et al., 2002].

[9] In the Baffin Bay, modern seismic refraction lines with ocean bottom seismometers are limited to the entrance of the Nares Strait [Jackson and Reid, 1994; Reid and Jackson, 1997], where Reid and Jackson [1997] interpret velocities of $6.8 \mathrm{~km} / \mathrm{s}$ as indication for serpentinized mantle rather than oceanic crust. The remainder of the Baffin Bay is only covered by short sonobuoy profiles (Figure 1), which show velocities compatible with oceanic crust [Keen and Barrett, 1972].

[10] In the Davis Strait, two lines from the NUGGET experiment [Funck et al., 2007; Gerlings et al., 2009] and a line along the Greenland coast [Gohl and Smithson, 1993] provide some information on the crustal structure in that region (Figure 1). NUGGET line 1 shows that southern Davis Strait is underlain by thinned continental crust with the exception of an area around the UFZ, where crust of an oceanic affinity was observed [Funck et al., 2007]. The oceanic crust is associated with pronounced gravity and magnetic anomalies that can be correlated through Davis Strait. This suggests that the UFZ acted as a leaky transform fault during phases of transtension. The 7 to $12-\mathrm{km}$-thick continental crust on NUGGET line 1 is underlain by a $\sim 5 \mathrm{~km}$ thick high-velocity zone (HVZ) that Funck et al. [2007] associate with southward flow of plume material along lithospheric thin spots beneath the Davis Strait region, similar to a model suggested earlier by Nielsen et al. [2002].

[11] While Funck et al. [2007] found no evidence for a HVZ beneath the thicker continental crust close to Greenland, Gohl and Smithson [1993] identified an up to 8-km-thick HVZ at the base of the Greenlandic crust, where the Moho depth varies between 30 to $42 \mathrm{~km}$. Gohl and Smithson [1993] interpret the HVZ to be associated with hot spot magmatism in the Davis Strait and Baffin Bay region. This magmatism is also observed along NUGGET line 2 (Figure 1), which extends from southern Davis Strait into northern Labrador Sea. Here, Gerlings et al. [2009] observed a $12-\mathrm{km}$-thick oceanic crust that is overlain by an up to 2-km-thick sequence of Palaeogene basalts. This is in the area of BGR line 77-6, where Chalmers and Laursen [1995] identified seaward-dipping reflections that are indicative of volcanic-style margins. Keen et al. [2012] also report seaward-dipping reflectors off Labrador. However, the volcanism is limited to the northern part of Labrador Sea. Farther south, the continental margins have a nonvolcanic character with serpentinised mantle in the continentocean transition zone [Chian et al., 1995b].

\section{Wide-Angle Seismic Experiment}

\subsection{Data Acquisition and Processing}

[12] Geophysical data were collected in September and October 2008 onboard the German research vessel Maria S. Merian [Gohl et al., 2009] including the three seismic refraction lines AWI20080500, AWI20080600 and AWI20080700. For simplicity, these lines are subsequently referred to as lines 500, 600, and 700 (Figures 1 and 2). This paper presents the results from line 600 , a $450-\mathrm{km}$ long transect (Figure 3) from the shelf off Baffin Island, across the southern Baffin Bay and onto the shelf off West Greenland. Close to the southeastern termination of line 600 , the location of the 3201-m-deep Hellefisk-1 well was crossed. Results from the crossing line 500 can be found in the work of Suckro et al. [2012]. Figure 2 shows the location of line 600 in a geological context. The characterization of basement types is primarily based on seismic reflection data, potential field data and plate reconstructions since seismic refraction data are scarce in this area (see 2.2 Previous Geophysical Studies).

[13] A total of 25 ocean bottom seismometers (OBS) were deployed at equal distances along the line (18.4 km spacing). The instruments were provided by IFM-GEOMAR (Kiel, Germany) and were equipped with a three-component $4.5-\mathrm{Hz}$ seismometer and a hydrophone [Gohl et al., 2009]. The seismic source consisted of $16 \mathrm{G}$. Guns ${ }^{\mathrm{TM}}$ ranging in size from 1.1 to $4 \mathrm{~L}$ ( 70 to $250 \mathrm{in}^{3}$ ) with a total volume of $50 \mathrm{~L}$ $\left(3100 \mathrm{in}^{3}\right)$ operated at a pressure of $145 \mathrm{bar}$. In addition, two Bolt guns with a volume of $32 \mathrm{~L}\left(1953 \mathrm{in}^{3}\right)$ each were used at a pressure of 80 bar (1160 psi). The shot interval was one minute, which resulted in an average shot spacing of $156 \mathrm{~m}$ at a variable ship speed of 4 to 5 knots. For navigation, the ship's Global Positioning System (GPS) system was used with an accuracy of 10-20 m [Gohl et al., 2009]. 


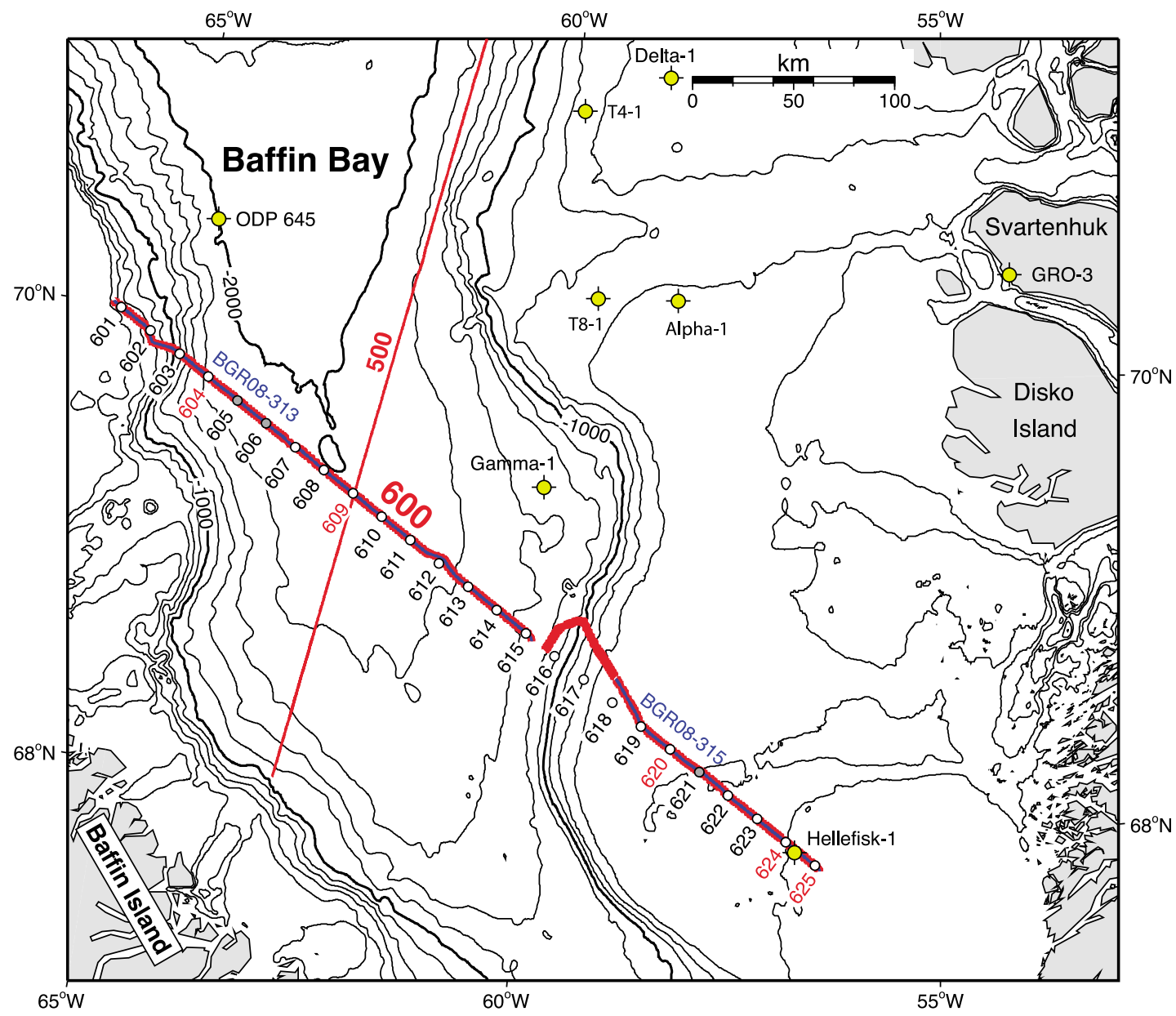

Figure 3. Location map of line 600 (full name: AWI20080600) of the MSM09/3 expedition. The red lines mark the shot locations along lines 600 and 500. White circles indicate the location of ocean bottom seismometers (OBS) on line 600, gray circles mark OBS with no data. The OBS station numbers are annotated (red annotations refer to OBS that are shown in Figures 4-8). Blue lines indicate segments of line 600 along which coincident seismic reflection data were collected [Gohl et al., 2009]. The bathymetry (GEBCO 08 grid) is plotted with solid lines; the contour interval is $200 \mathrm{~m}$.

[14] The shots were simultaneously recorded by a 3450-m-long digital streamer (SEAL system by Sercel) with 276 channels. The purpose of the coincident seismic reflection line was to assist the velocity modeling of the seismic refraction data by providing detailed information on the geometry of the basement and sedimentary layers.

[15] During the shooting of line 600, the vessel encountered an area with active fishing at the seaward limit of the Greenland shelf. This happened at night during a heavy snow storm with a visibility well below $50 \mathrm{~m}$. For this reason, the streamer had to be recovered and the ship detoured to the north (Figure 3). This resulted in a kink in the line with shots being offset by up to $23 \mathrm{~km}$ from the deployed positions of OBS 616,617 and 618 . As discussed later, the resolution of the velocity model is reduced in this zone.

[16] After recovery of the OBS, the data were dumped to disk, corrected for OBS clock drift, converted to SEG-Y format, and debiased. Travel time picks of the direct wave were used to recalculate the position of the instruments at the seafloor using a least squares method and velocity-depth profiles for the water column obtained from CTD (conductivity, temperature, depth) measurements. Shot-receiver ranges were calculated from the new OBS locations. Record sections are displayed with a band-pass filter from 8 to $24 \mathrm{~Hz}$ (Figures 4-8). Deconvolution improved the recognition of seismic phases to some extent but was less successful in the shallow water where the large Bolt guns produced significant reverberations. Trace amplitudes in the record sections are weighted by their distance to the OBS to increase amplitudes for large offsets.

\subsection{Methodology}

[17] The goal of the analysis of the seismic refraction data was to obtain a two-dimensional velocity model for the sediments, volcanics, crust, and uppermost mantle. Line 600 was shot along a great circle arc with the exception of the off-line shots due to fishing vessels. This arc forms the baseline for the model with the origin $(\mathrm{x}=0 \mathrm{~km})$ defined by the northwestern-most shot.

[18] The $P$ wave velocity model was developed using the program RAYINVR [Zelt and Smith, 1992; Zelt and 

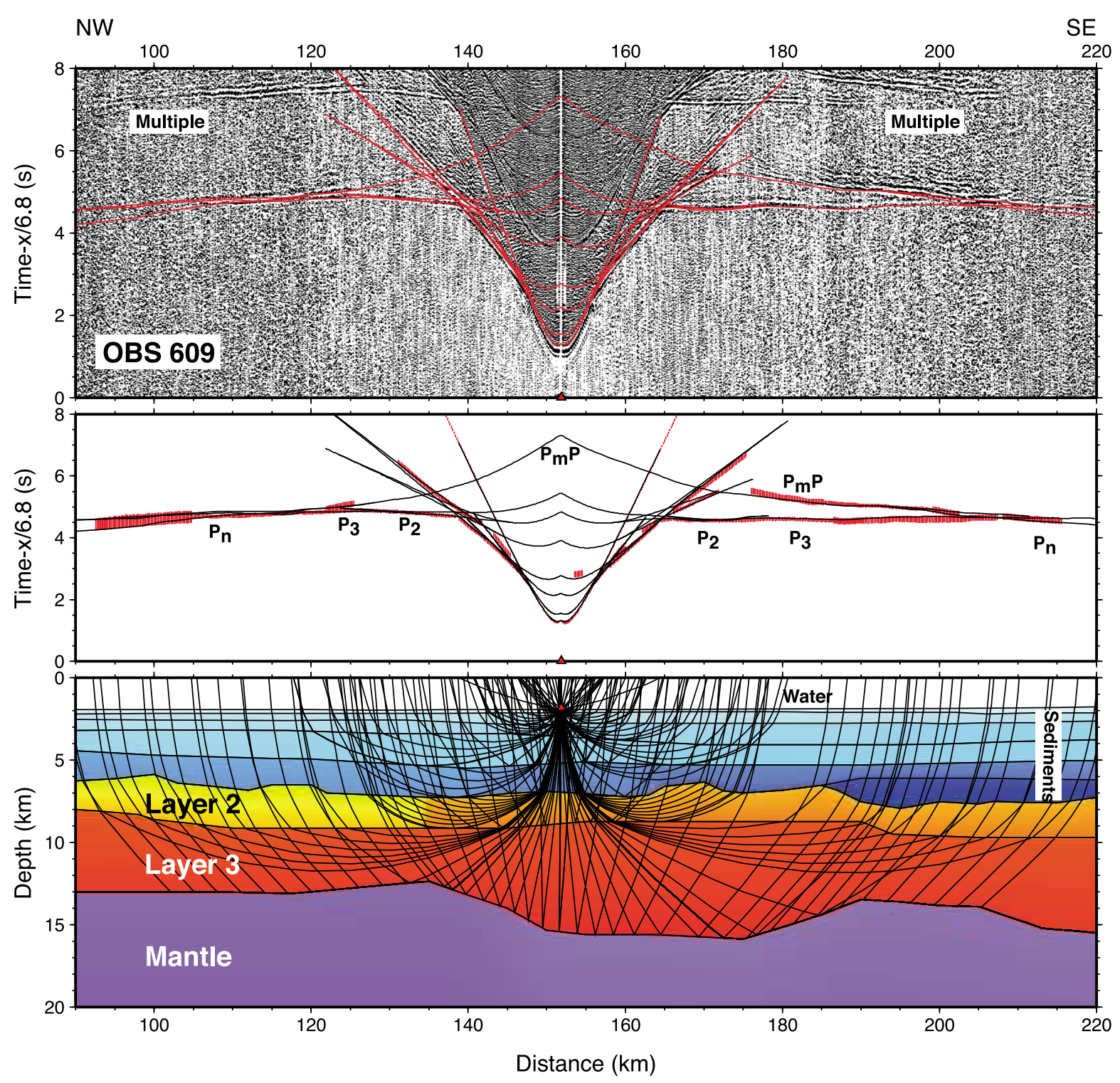

Figure 4. Seismic record, raypaths and travel times for OBS 609. (top) Record section of hydrophone component with calculated travel times (red lines), (middle) calculated travel time (black lines) with observed travel times (red lines), and (bottom) raypaths through the velocity model (same color scheme as in Figure 9). The uncertainty of the observed travel times is given by the height of the vertical bars. Travel times are displayed with a reduction velocity of $6.8 \mathrm{~km} / \mathrm{s}$. The horizontal scale is distance along the velocity model. A red triangle marks the OBS position. For phase names see also Table 1.

Forsyth, 1994], which allows both for forward and inverse modeling. Initially, a forward model was developed from top to bottom (seafloor to mantle) by fitting the observed travel times. Layer boundaries within the sediments and the basement geometry were taken from the coincident seismic reflection record whenever the data quality allowed for this. However, the low fold of the seismic reflection data, the location of the seabed multiple, and the gap in the reflection data due to the deviation around fishing vessels, prevent a clear definition of the basement along most portions of line 600. After the development of the initial forward model, both layer boundaries and velocities within layers were optimized by using the inversion algorithm in RAYINVR. Gravity data were used to help defining the deep structures at the edges of the line without ray coverage (see section 4.3).

\subsection{Seismic Data}

[19] Three of the 25 OBS had technical problems, which prevented the recording of data (OBS 605, 606 and 621). Most records exhibit a high signal-to-noise ratio that allow for the identification of seismic phases down to the mantle (mantle refraction $P_{n}$ ) as for example on OBS 609 (Figure 4). The Moho reflection $\left(P_{m} P\right)$ can be recognized on most records, in particular for OBS's on crust with oceanic affinity (Figure 4) but also in the continental domain (Figure 5). Most instruments between OBS 604 and 619 show a prominent refraction that is approximately horizontal when plotted with 


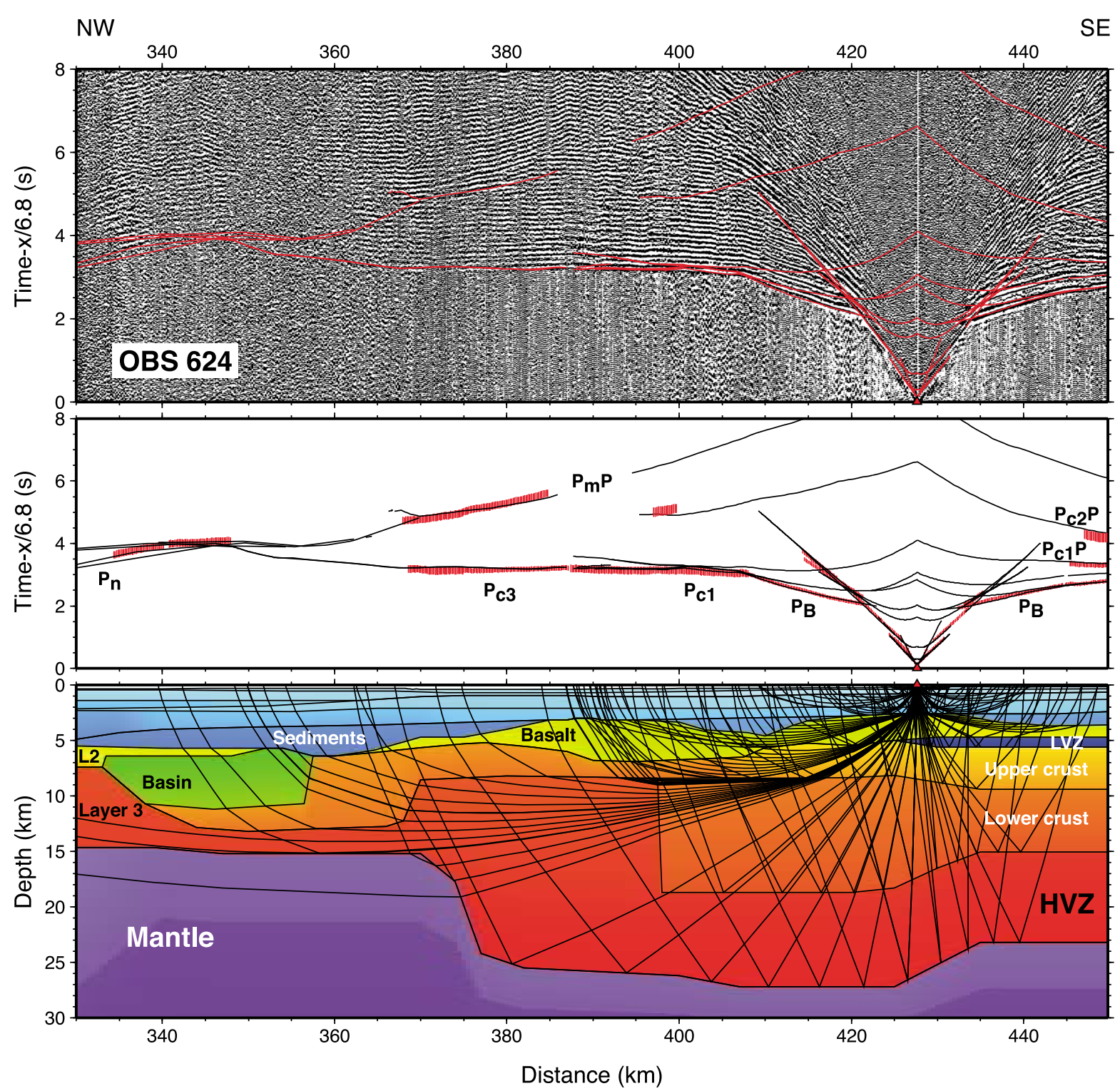

Figure 5. Seismic record, raypaths and travel times for OBS 624 (hydrophone component). For details see caption for Figure 4. For phase names see also Table 1. Abbreviations are HVZ, high-velocity zone; L2, oceanic layer 2; LVZ, low-velocity zone.

a reduction velocity of $6.8 \mathrm{~km} / \mathrm{s}$ (e.g., Figure 4 ). This indicates the presence of a crustal layer with a velocity around $6.8 \mathrm{~km} / \mathrm{s}$, which is very typical for layer 3 in oceanic crust [White et al., 1992].

[20] Three important record sections are discussed here in more detail. OBS 625 (Figure 6) at the SE end of line 600 shows a high-amplitude mid-crustal reflection $\left(P_{c 1} P\right)$. Such mid-crustal reflections are generally not observed in oceanic crust as there is a rather smooth transition from the upper to lower crustal velocities [cf. White et al., 1992]. In contrast, mid-crustal reflections are very typical for continental crust [Mooney and Brocher, 1987; Funck and Louden, 1999; Funck et al., 2000b, 2003]. Hence, this reflection is regarded as an indication for the presence of continental crust at this part of the line. Further evidence is provided by the observed velocities (see section 4.1).
[21] A second feature to be discussed for OBS 625 (Figure 6) is the occurrence of a low-velocity zone that is revealed by a time delay ("jump") in the first arrivals some $30 \mathrm{~km}$ to the NW of the OBS (at a distance of $417 \mathrm{~km}$ ). At this distance, the refraction within the volcanic layer (labeled $P_{B}$ and inferred from correlation with the Hellefisk-1 well) disappears and some $200 \mathrm{~ms}$ later another refraction $\left(P_{c l}\right.$, within the upper crust) becomes the new first arrival. Such a time delay can only be generated by a layer between the volcanic layer and the upper crust with a velocity lower than in the volcanic layer. Velocities within such a low-velocity zone (LVZ) cannot be constrained due to the lack of refractions (see also section 4.2).

[22] One OBS that was very difficult to model was OBS 620 (Figure 7). This was due to a very complex geometry close to that OBS with a deep basin that caused problems with phase identification. A strong reflection at a distance of 


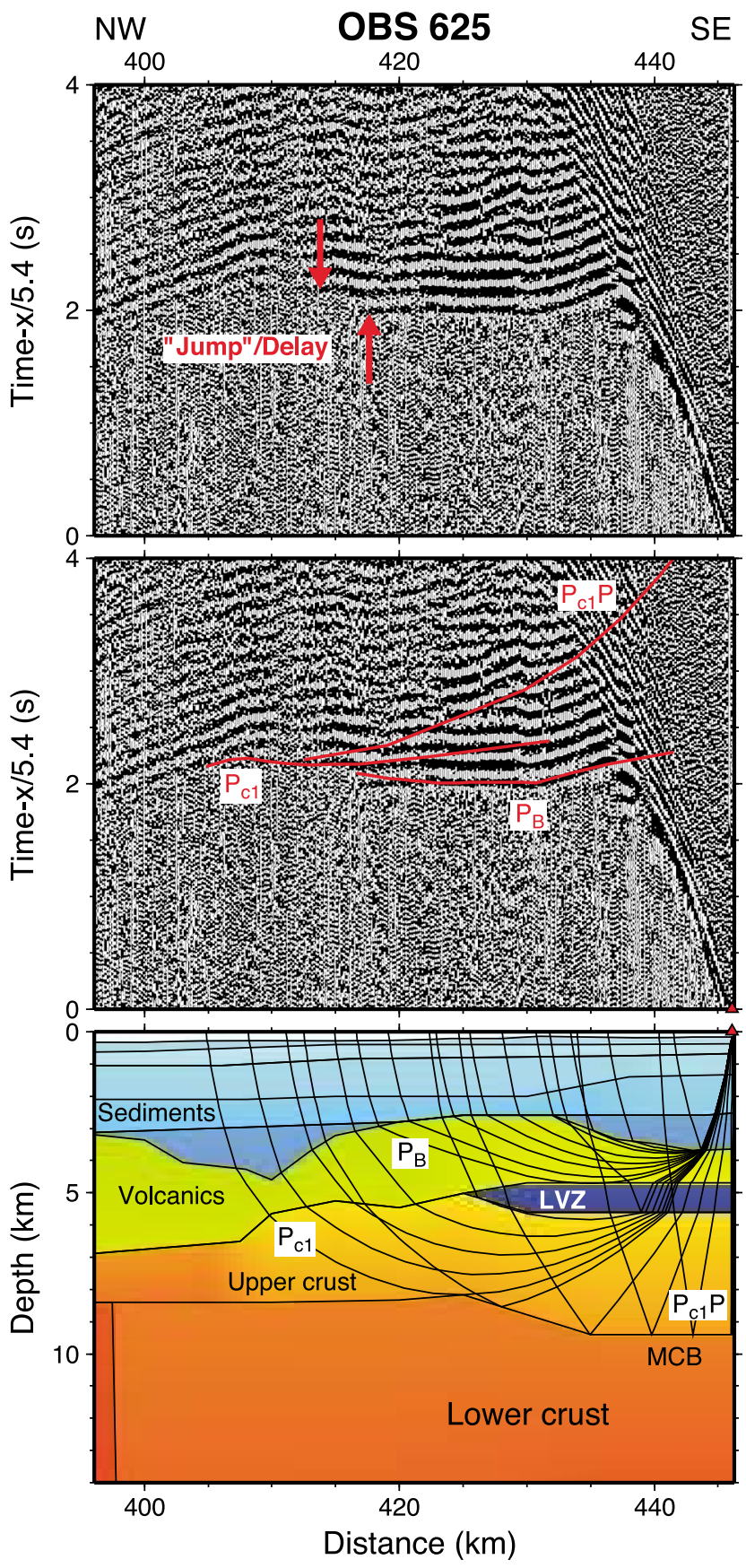

Figure 6. (top) Part of record section of OBS 625 (hydrophone component) displayed with a reduction velocity of $5.4 \mathrm{~km} / \mathrm{s}$. The horizontal scale is distance along the velocity model. (middle) The same record shown together with calculated travel times (red lines) for some selected phases. (bottom) The corresponding velocity model (same color scheme as in Figure 9) with the raypaths of the selected phases. The red triangle marks the position of the OBS. For phase names see also Table 1. Abbreviations are LVZ, low-velocity zone; MCB mid-crustal boundary.

330 to $335 \mathrm{~km}$ was initially thought to be the Moho reflection $P_{m} P$. However, later it was determined to be a reflection from the base of the basin. The most important phase on this record is the $P_{2}$ refraction - a phase that is very difficult to spot due to its low amplitude. The velocity $(5.5 \mathrm{~km} / \mathrm{s})$ is similar to that observed in the upper crust between 317 and $330 \mathrm{~km}$. However, using a velocity of $5.5 \mathrm{~km} / \mathrm{s}$ for the entire basin cannot explain the time delay for deep crustal phases

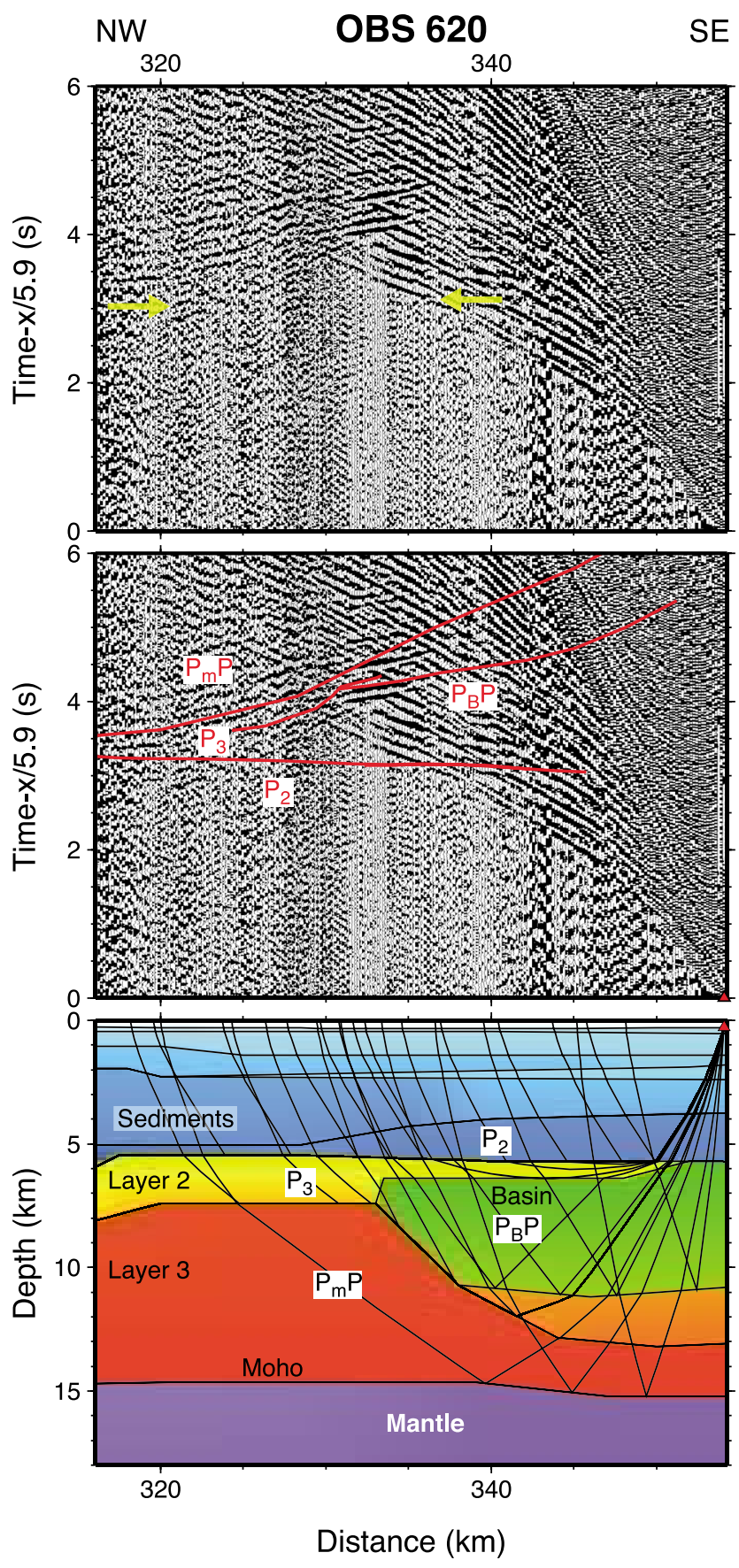

Figure 7. (top) Part of record section of OBS 620 (hydrophone component) displayed with a reduction velocity of $5.9 \mathrm{~km} / \mathrm{s}$. The horizontal scale is distance along the velocity model. Yellow arrows indicate the zone where the weak $P_{2}$ phase can be correlated. (middle) The same record shown together with calculated travel times (red lines) for some selected phases. (bottom) The corresponding velocity model (same color scheme as in Figure 9) with the raypaths of the selected phases. The red triangle marks the position of the OBS. For phase names see also Table 1. 


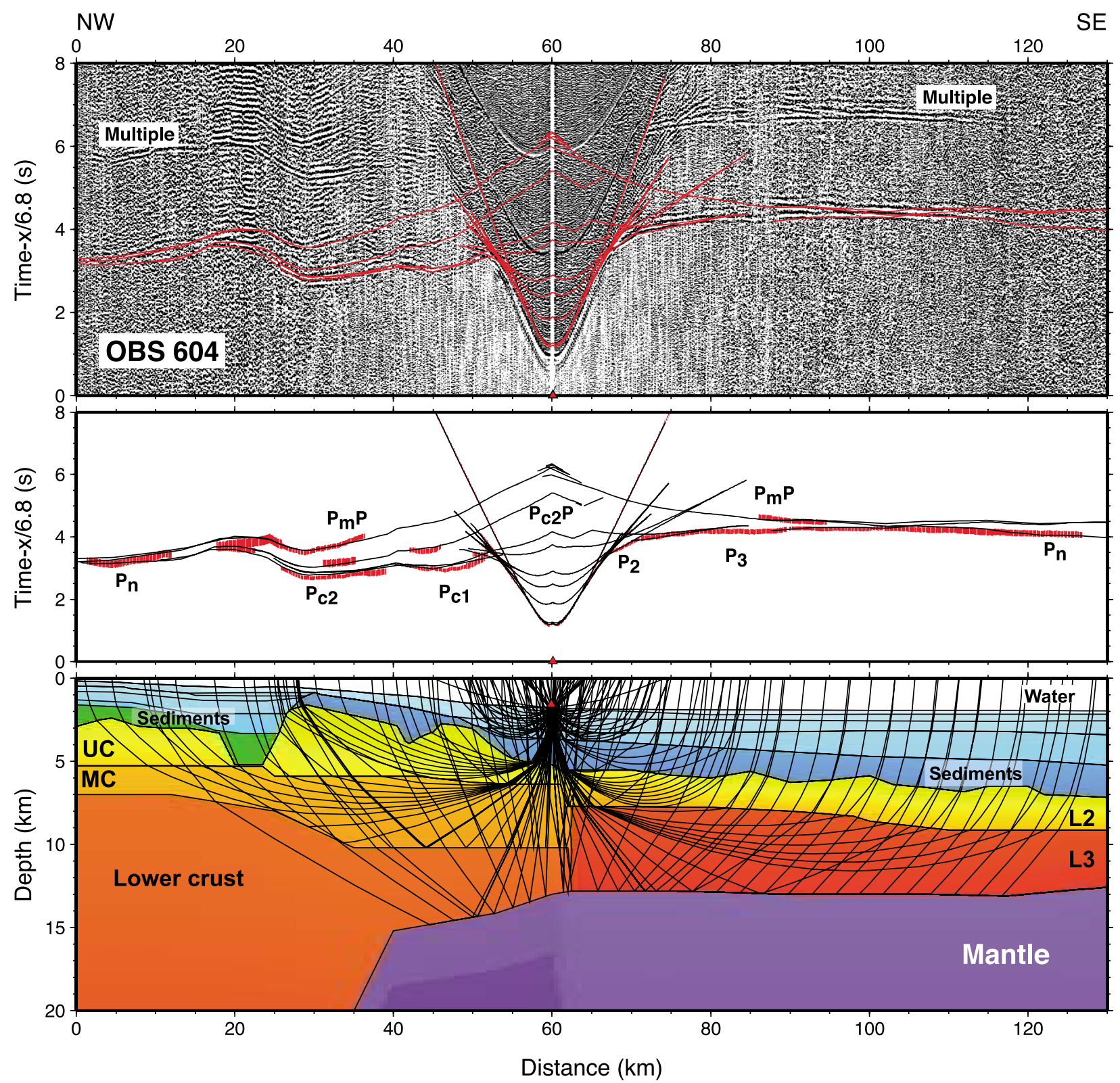

Figure 8. Seismic record, raypaths and travel times for OBS 604 (hydrophone component). For details see caption for Figure 4. For phase names see also Table 1. Abbreviations are L2, oceanic layer 2; L3, oceanic layer 3; MC, mid-crustal layer; UC, upper crust.

observed on instruments farther to the SE. This is why velocities $<5.5 \mathrm{~km} / \mathrm{s}$ had to be used for the basin. To match the observed $P_{2}$ phase at OBS 620 (Figure 7), a thin layer with a velocity of $5.5 \mathrm{~km} / \mathrm{s}$ was introduced at the top of the basin. Overall, the raypaths were very sensitive to even slight changes in the basin like velocities, steepness of the flanks, and thickness of the top layer. This made it difficult to obtain an acceptable fit for all the observed seismic phases.

[23] OBS 604 (Figure 8) is located at the position where an abrupt lateral change in the crustal velocities had to be introduced. To the southeast, an oceanic velocity structure is encountered with the $P_{2}$ and $P_{3}$ refractions. Crustal refractions in the northwest $\left(P_{c 1}\right.$ and $\left.P_{c 2}\right)$ arrive earlier due to the shallowing of the basement. The phase velocity of the $P_{c 2}$ refraction is higher than that of the $P_{3}$ phase in oceanic layer 3 . However, this apparent higher velocity is also related to the northwestward shallowing of the basement. The actual modeled velocity in the mid-crustal layer through which the $P_{c 2}$ is propagating, is only $6.1 \mathrm{~km} / \mathrm{s}$. This compares to $6.8 \mathrm{~km} / \mathrm{s}$ in oceanic layer 3 . The change from oceanic to continental crust around $60 \mathrm{~km}$ is also indicated by the presence of a mid-crustal reflection $\left(P_{c 2} P\right)$ to the northwest that is not observed to the southeast.

[24] Off Greenland, the $P_{c 2} P$ phase (Figure 5) marks the top of a high-velocity lower crustal layer. In order to obtain a visible $P_{c 2} P$ reflection, velocities have to increase from the constrained $6.8 \mathrm{~km} / \mathrm{s}$ at the base of the lower crust to values $>7.0 \mathrm{~km} / \mathrm{s}$ below. As there are no refractions within the high-velocity zone, there are no direct constraints on its 
velocity. However, the presence of high velocities as deduced from the $P_{c 2} P$ reflections is consistent with the better constrained results from NUGGET line 1 in southern Davis Strait [Funck et al., 2007].

\section{Results}

[25] Below, the $P$ wave velocity model for line 600 is presented. First, the model is described followed by a detailed account of the model resolution and uncertainties. Finally, two-dimensional gravity modeling is employed to check for consistency of the velocity model with the observed gravity data.

\subsection{Velocity Model}

[26] The $P$ wave velocity model for line 600 is shown in Figure 9. Although some interpretation of the observed velocity structure is given here, a more detailed account can be found in the next section (section 5). The upper part of the model consists of a series of sediment layers. In the central part of the line in the deep basin of Baffin Bay, velocities within the sedimentary layers vary from 1.6 to $4.2 \mathrm{~km} / \mathrm{s}$ and the total thickness reaches $6 \mathrm{~km}$. However, the velocities of $1.6 \mathrm{~km} / \mathrm{s}$ close to the seafloor are not constrained by any refractions. In the NW beneath the Baffin Island shelf, the lowermost sediment layer is modeled with a velocity of 4.3 to $4.4 \mathrm{~km} / \mathrm{s}$. On the Greenland side velocities are not as high; sediments above the volcanic basement reach a velocity of $3.8 \mathrm{~km} / \mathrm{s}$. However, the maximum sediment thickness on line 600 is slightly higher off Greenland than off Baffin Island with values of 6 and $5 \mathrm{~km}$, respectively.

[27] Volcanic rocks were drilled in the lower section of the Hellefisk-1 well. The velocity model (Figure 9) shows velocities of 5.2 to $5.7 \mathrm{~km} / \mathrm{s}$ that are consistent with a volcanic layer with a maximum layer thickness of $4 \mathrm{~km}$. This thickness is quite variable as the volcanic sequence consists of two mounded structures. The minimum thickness is as little as $1 \mathrm{~km}$. To the northwest, the layer pinches out at $365 \mathrm{~km}$. Between 333 and $357 \mathrm{~km}$ another layer appears with velocities of 4.7 to $4.9 \mathrm{~km} / \mathrm{s}$ (poorly constrained) and a thickness of $5 \mathrm{~km}$. This layer forms a basin. At the SE end of the line, a low-velocity zone (LVZ) is observed beneath the basalts. The modeled velocity is $4.1 \mathrm{~km} / \mathrm{s}$ within the LVZ, but it should be emphasized here that the velocity within the LVZ is not constrained due to the absence of refractions; even the depth of the top of the LVZ is undefined. However, the seismic reflection data indicate the disappearance of high-amplitude reflections at that depth level. The velocity in this layer is $<5.6 \mathrm{~km} / \mathrm{s}$ but the composition remains unclear (basalts or non-volcanic sediments). Other, local LVZs are observed within the sedimentary column.

[28] The crust shows large lateral variations both in velocity and thickness (Figure 9). Between 0 and $60 \mathrm{~km}$, the crust is modeled with three layers with velocities of 5.5$5.9 \mathrm{~km} / \mathrm{s}$ in the upper crust, 6.1 to $6.3 \mathrm{~km} / \mathrm{s}$ at mid-crustal levels and 6.6 to $6.9 \mathrm{~km} / \mathrm{s}$ within the lower crust. This velocity distribution and the occurrence of mid-crustal reflections are consistent with continental crust [Mooney and Brocher, 1987]. Rough basement topography with three basement highs and a seaward shallowing of the Moho indicates that the crust has been faulted and thinned. The
Moho depth is only constrained between 40 and $60 \mathrm{~km}$ where it shallows from 15 to $13 \mathrm{~km}$. The landward deepening of the Moho between 0 and $40 \mathrm{~km}$ is inferred from the gravity modeling (see section 4.3.).

[29] As discussed in section 3.3, a rather abrupt velocity change occurs at $60 \mathrm{~km}$. Between 60 and $333 \mathrm{~km}$, the crust is divided into an upper and lower crustal layer interpreted as oceanic layers 2 and 3 (Figure 9). Velocities within layer 3 are fairly constant and around $6.8 \mathrm{~km} / \mathrm{s}$ at the top and 7.0 to $7.2 \mathrm{~km} / \mathrm{s}$ at the base as is typical for oceanic crust [White et al., 1992]. Layer 2 velocities can be divided laterally into three segments: between 60 and $135 \mathrm{~km}$ velocities range from 5.5 to $6.0 \mathrm{~km} / \mathrm{s}$, between 135 and $227 \mathrm{~km}$ there is an increase to 6.1 to $6.5 \mathrm{~km} / \mathrm{s}$, and between 227 and $333 \mathrm{~km}$ velocities decrease again to 5.5 to $6.0 \mathrm{~km} / \mathrm{s}$. The thickness of layer 2 is generally around $2 \mathrm{~km}$, but locally exceeds $3 \mathrm{~km}$. The total oceanic crustal thickness varies from 5 to $9 \mathrm{~km}$ and the Moho discontinuity is located at depths between 13 and $16 \mathrm{~km}$. The previously discussed basin between 333 and $357 \mathrm{~km}$ is partly covered by a thin layer with a velocity of $5.5 \mathrm{~km} / \mathrm{s}$, which is similar to the adjacent oceanic layer 2. The exact thickness of this layer, which is assumed to be basaltic, is not determined seismically. The model shows a termination of this layer at $352 \mathrm{~km}$ as there was no seismic evidence for a continuation to the SE.

[30] Crustal velocities beneath the basin (333 to $357 \mathrm{~km}$ ) are not constrained seismically. However, reflections from the base of the basin and from the Moho give a thickness estimate of $4 \mathrm{~km}$ for the crust in this zone (Figure 9). Farther to the SE, the crust thickens substantially; the Moho deepens from $15 \mathrm{~km}$ beneath the basin to $26 \mathrm{~km}$ between 380 and $400 \mathrm{~km}$. In this zone, two crustal layers can be distinguished with velocities of 6.3 to $6.6 \mathrm{~km} / \mathrm{s}$ and 6.8 to $7.3 \mathrm{~km} / \mathrm{s}$ in the upper and lower layer, respectively. This crust is interpreted as thick igneous crust. Farther to the SE toward Greenland, crustal velocities decrease and this, together with the observations of mid-crustal reflections, suggest a continental character of the crust. In the upper continental crust, velocities range from 5.8 to $6.2 \mathrm{~km} / \mathrm{s}$ while the lower crust exhibits velocities from 6.5 to $6.8 \mathrm{~km} / \mathrm{s}$. The upper crust is between 3 and $4 \mathrm{~km}$ thick, while the lower crustal thickness decreases from $10 \mathrm{~km}$ in the NW to $6 \mathrm{~km}$ in the SE. Beneath the continental crust, another layer was introduced into the model to explain a set of reflections $\left(P_{c 2} P\right)$. These phases originate from a depth level that is shallower than the Moho in the zone that is adjacent to the thick igneous crust. This observation was accommodated by continuing the high velocities of the igneous crust beneath the continental crust and is interpreted as magmatic underplating. Velocities in this high-velocity zone (HVZ) are not constrained due the lack of refractions from this layer. However, the velocity change in the model from $6.8 \mathrm{~km} / \mathrm{s}$ at the base of the lower continental crust to $7.1 \mathrm{~km} / \mathrm{s}$ at the top of the HVZ yields in an impedance contrast that is sufficient to create detectable reflections. Funck et al. [2007] found a similar and wellresolved underplated layer in the southern Davis Strait, where the velocity was $7.4 \mathrm{~km} / \mathrm{s}$. This gives an idea of the possible range of velocities in the HVZ. Mantle velocities within the oceanic domain were modeled between 7.8 and $7.9 \mathrm{~km} / \mathrm{s}$. Beneath the continental crust off Baffin Island, mantle velocities of $8.0 \mathrm{~km} / \mathrm{s}$ were used in the model. 

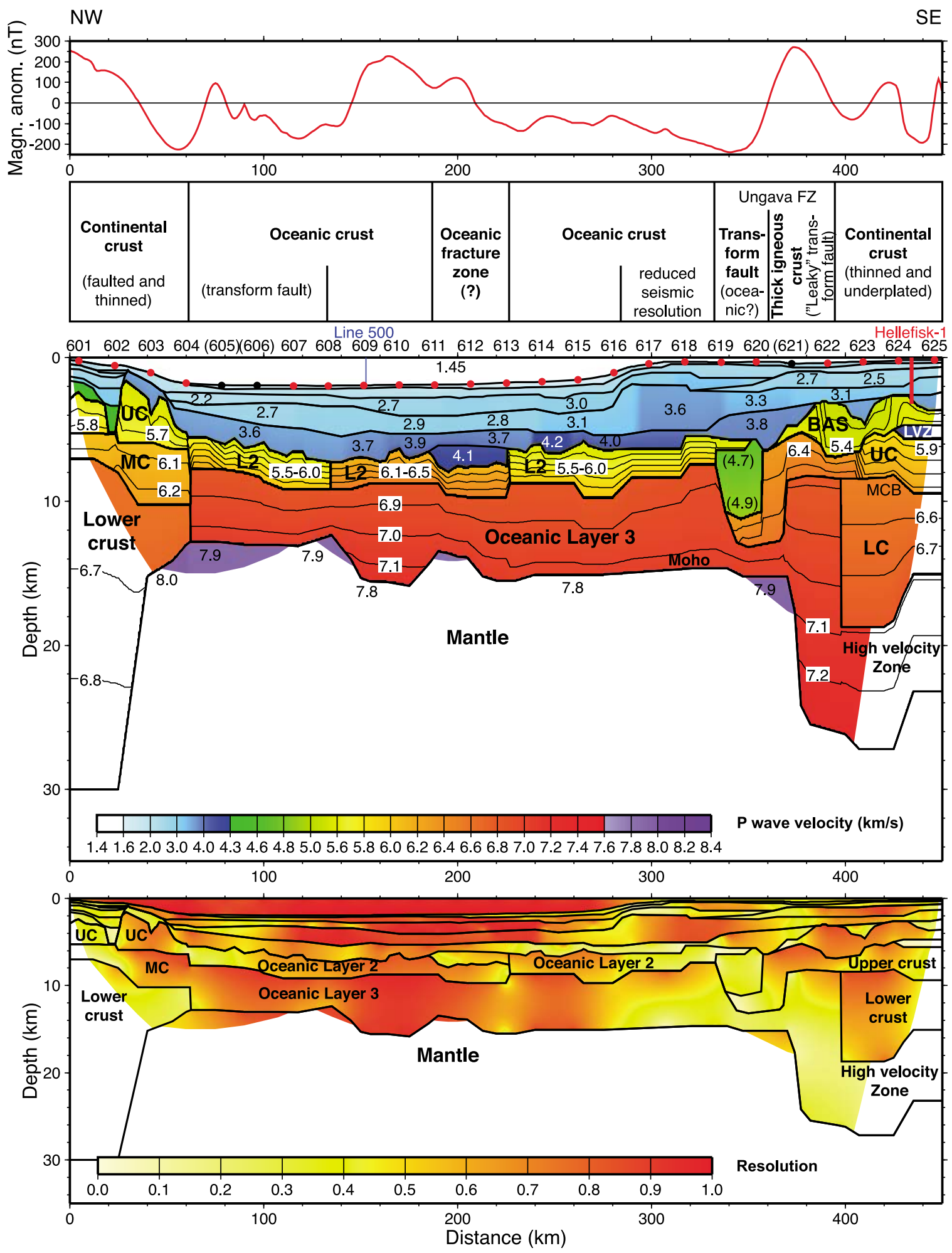

Figure 9. (top) Magnetic anomalies, (middle) $P$ wave velocities with interpretation, and (bottom) diagonal values of the resolution matrix of the $P$ wave velocity model along line 600 . Data source for the magnetic data: Verhoef et al. [1996]. The outer parts of the velocity model and of the resolution matrix with no ray coverage are shown in white, velocities are specified in $\mathrm{km} / \mathrm{s}$, the velocity contour interval is $0.1 \mathrm{~km} / \mathrm{s}$. Red circles show the location of OBS's that were used for the modeling, the black circles refer to nonfunctional OBS's. The location of the Hellefisk-1 well and the cross-point with refraction line 500 are indicated by a red and blue line, respectively. Abbreviations are BAS, basalts/volcanic rocks; FZ, fault zone; MCB, mid-crustal boundary; L2, oceanic layer 2; LC, lower crust; LVZ, low-velocity zone; MC, midcrustal layer; MCB, mid-crustal boundary; UC, upper crust. 
Table 1. Number of Observations, $n$, RMS Misfit Between Calculated and Picked Travel Times, $t_{r m s}$, and Normalized $\chi^{2}$ for Individual Phases on Line 600

\begin{tabular}{lrcc}
\hline \multicolumn{1}{c}{ Phase } & \multicolumn{1}{c}{$n$} & $t_{r m s}(\mathrm{~s})$ & $\chi^{2}$ \\
\hline Direct wave & 1735 & 0.026 & 0.379 \\
$P_{S}$ (all sediment refractions) & 3129 & 0.045 & 0.354 \\
$P_{S} P$ (all sediment reflections) & 1337 & 0.096 & 1.683 \\
$P_{B}$ (refraction in basalt) & 585 & 0.048 & 0.441 \\
$P_{B} P$ (reflection base basalt) & 45 & 0.046 & 0.214 \\
$P_{2}$ (refraction in oceanic layer 2) & 1532 & 0.132 & 0.913 \\
$P_{3}$ (refraction in oceanic layer 3) & 3518 & 0.068 & 0.575 \\
$P_{c 1}$ (refraction in upper crust) & 747 & 0.066 & 0.724 \\
$P_{c 1} P$ (reflection base upper crust) & 102 & 0.045 & 0.372 \\
$P_{c 2}$ (refraction in mid-crustal layer) & 882 & 0.090 & 0.859 \\
$P_{c 2} P$ (reflection base mid-crustal layer) & 255 & 0.094 & 0.521 \\
$P_{c 3}$ (refraction in lower crust) & 30 & 0.035 & 0.197 \\
$P_{m} P$ (Moho reflection) & 1670 & 0.077 & 0.619 \\
$P_{n}$ (refraction in mantle) & 2177 & 0.113 & 0.876 \\
All phases & 17744 & 0.080 & 0.683 \\
\hline
\end{tabular}

\subsection{Model Resolution and Uncertainty}

[31] To assess the resolution and uncertainty of the velocity model, a formal error analysis for individual phases is given next to plots showing the ray coverage. In addition, the values of the diagonal of the resolution matrix for the velocity nodes are calculated. The resolution matrix is a good indicator that distinguishes between poor and well resolved parts of a model. Ideally, values of the resolution matrix are 1 but values $>0.5$ indicate reasonably well resolved model parameters [Lutter and Nowack, 1990].

[32] The formal error analysis for individual phases on line 600 is summarized in Table 1 . The normalized $\chi^{2}$ is based on assigned pick uncertainties of 40-200 ms depending on the quality of each individual travel time pick. Pick uncertainties are graphically indicated in Figure 10. The model is generally well constrained with a total RMS misfit of $80 \mathrm{~ms}$ between calculated and picked travel times. This is close to the average travel time uncertainty of $83 \mathrm{~ms}$. The normalized $\chi^{2}$ of 0.68 is below the optimum value of 1 when travel times are fitted within the given pick uncertainty. This could indicate that either the model was fit to noise in the data or the pick uncertainties were overestimated.

[33] The diagonal values of the resolution matrix of the velocity nodes are shown in a gridded version in Figure 9 and show a close correlation with the ray coverage (Figure 10). That is, areas with good and reversed ray coverage are characterized by high resolution values. Within the sedimentary column, velocities are generally well resolved, although there are some exceptions. In the area where the ship deviated from the track line (ca. 265 to $335 \mathrm{~km}$ ), there are zones with reduced resolution that are caused by lack of observations (absence of close offset shots) or by complexities associated with the three-dimensionality introduced by the off-line shots. During the modeling, large lateral variations were avoided within that area. In this zone, the observed seismic phases are generally consistent with the velocities in the adjacent areas with online shots. However, an offset in time is often noticed, which indicates a change in the sedimentary thickness perpendicular to the line. In these cases, the offset was accepted because no consistent twodimensional model could be found that would explain all the observations within this zone. Thus, the velocity model is representative for the location of the OBS rather than for the off-line shot locations. Phases that displayed these problems were not included in the error analysis. Another zone with poor resolution is within the sediments on the Baffin Island shelf between 0 and $30 \mathrm{~km}$, where low-velocity zones occur and where not all raypaths are reversed.

[34] The low-velocity zone beneath the basalts at the southeastern end of the profile is not well resolved. However, this is the nature of low-velocity zones in which no refractions can be observed which would allow for a direct determination of the velocity. The existence of the lowvelocity zone is well constrained as seen by the characteristic delay of refractions (Figure 6). Similar, the low resolution in the basin between 333 and $357 \mathrm{~km}$ is related to the complexities in the velocity structure there. The data cannot be explained without a basin at that location that is covered by a thin layer with a higher velocity than in the underlying sediments. The reduced resolution reflects the uncertainty of the thickness of the overlying layer and the velocity within the basin.

[35] Velocities within the oceanic crust are well resolved (Figure 9), but as before, the resolution decreases in the region where the ship deviated from the line during the shooting. Nevertheless, some $P_{3}$ rays sampled the lower crust in this region and are consistent with layer 3 velocities farther to the NW. Also the few $P_{2}$ observations are consistent with layer 2 velocities outside this zone. However, no $P_{n}$ or $P_{m} P$ phases are observed between 280 and $335 \mathrm{~km}$, which could determine the Moho depth. As mentioned above, velocities within low-velocities zones cannot be resolved and a resolution value of 0.3 in the basin around $340 \mathrm{~km}$ indicates uncertainty in the velocities there. Reduced resolution within the crust close to the outer limit of the model coincides with a decrease of the number of reversed raypaths in these areas. The lower crust around $390 \mathrm{~km}$ has well resolved velocities at the top (resolution values of 0.7 0.8 ), but at the bottom and within the adjacent HVZ, velocities are only poorly resolved. Mantle velocities display resolution values up to 0.9 in areas where $P_{n}$ phases are observed. The plot with the ray coverage (Figure 10) also indicates the segments of layer boundaries that are constrained by wide-angle reflections.

[36] Absolute errors of the model can be estimated by perturbation of single nodes (velocity and boundary nodes) in the model and examination of the sensitivity of the travel times to these perturbations. Such a test was performed within the basin between 333 to $357 \mathrm{~km}$ (Figure 9). It was found that velocities that deviate $\pm 0.4 \mathrm{~km} / \mathrm{s}$ from the modeled 4.7 to $4.9 \mathrm{~km} / \mathrm{s}$ can still explain most of the travel time observations, although it becomes increasingly difficult to fit all observations once the velocities are varied by more than $\pm 0.2 \mathrm{~km} / \mathrm{s}$.

[37] Line 600 offers another opportunity to check the accuracy of the velocity model since the line crosses the Hellefisk-1 well. Figure 11 shows a comparison of the velocity model with the sonic log from the well (obtained from GEUS data repository). To reduce the scatter in the sonic log data, a median filter with a filter length of $20 \mathrm{~m}$ was used. It should also be noted that the log data were not used to adjust the velocity model; only the wideangle reflections and refractions as well as the coincident seismic reflection data were used for the modeling. There is 

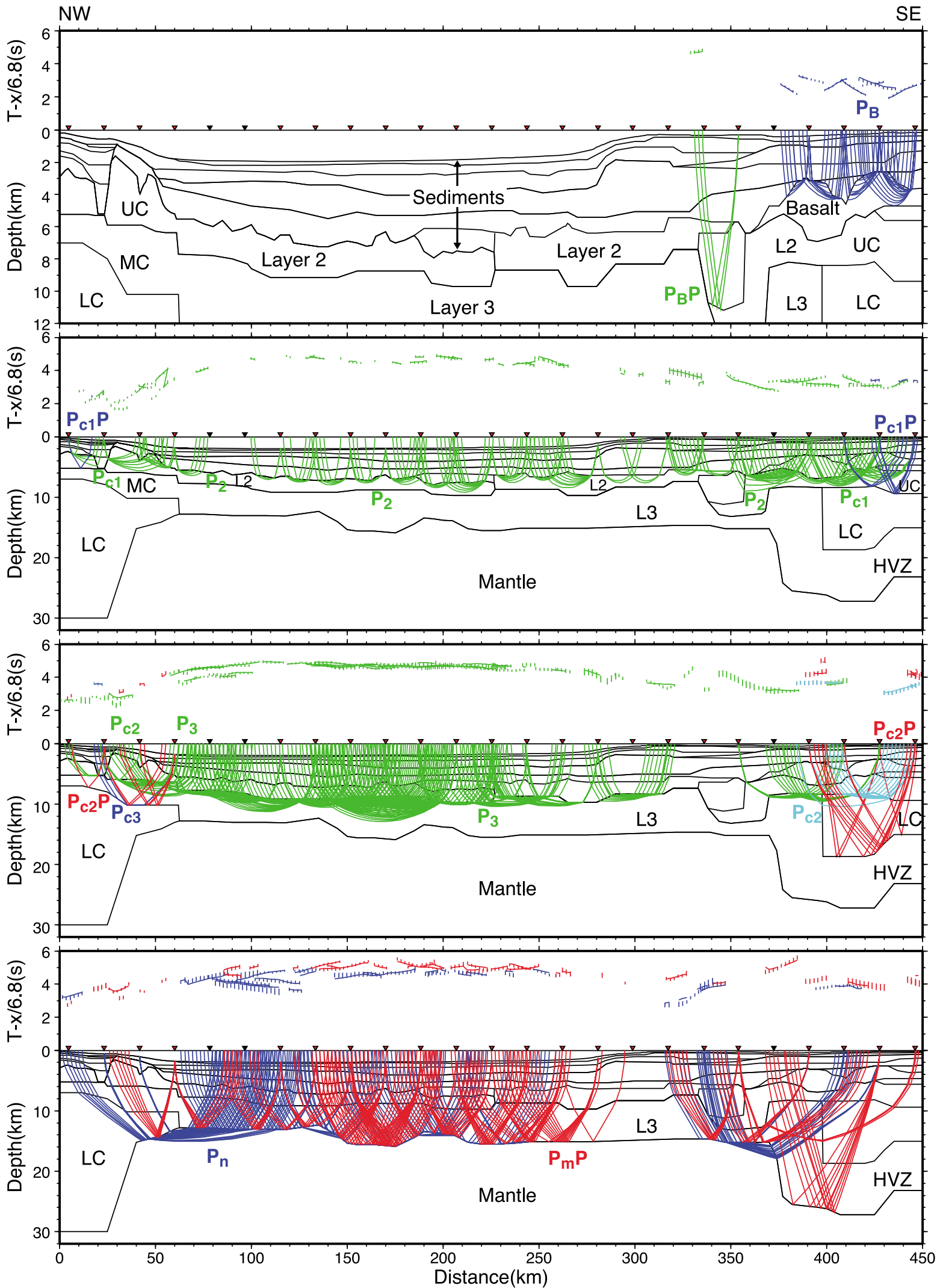

Figure 10 


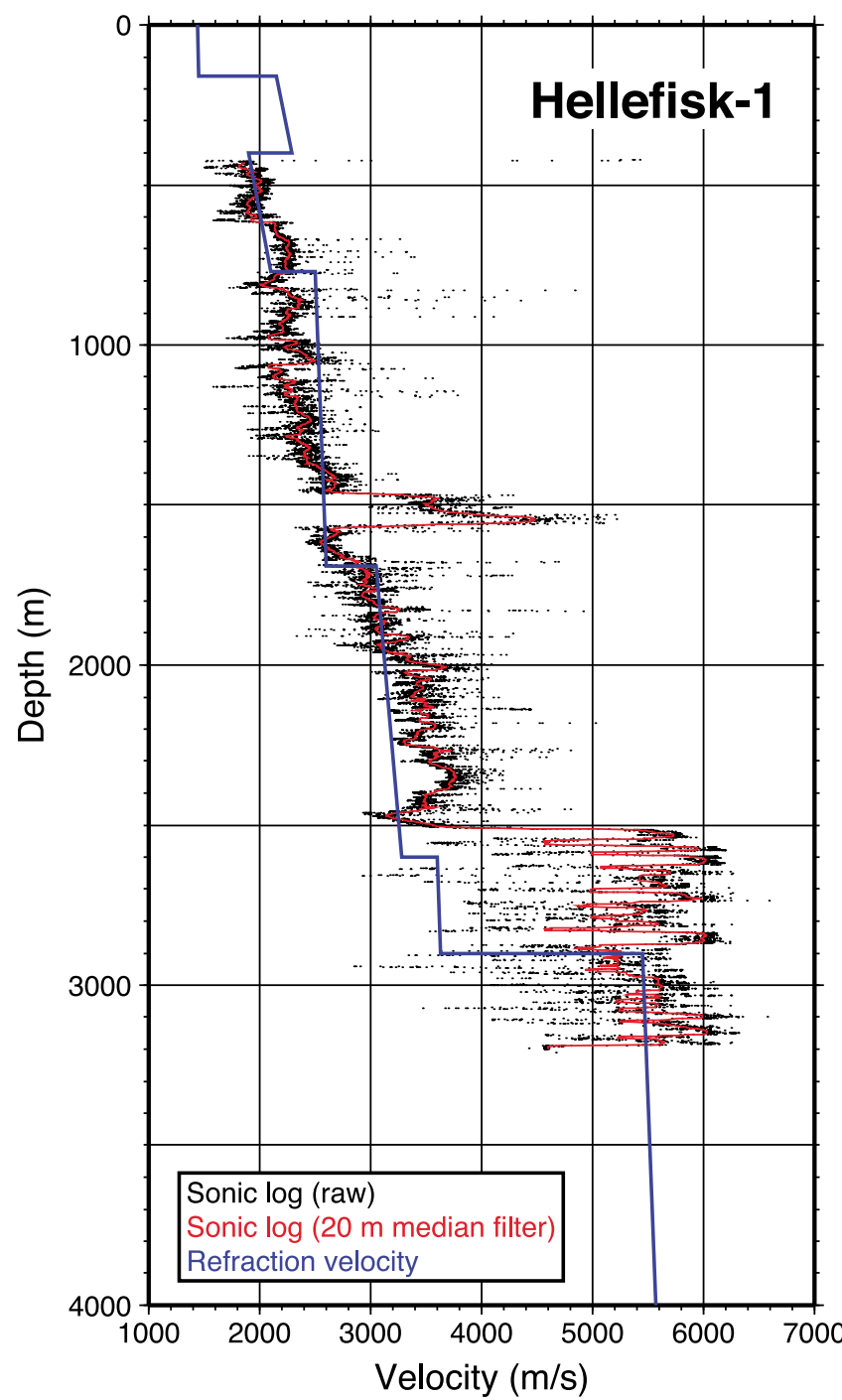

Figure 11. Comparison of the sonic log velocities from the well Hellefisk-1 (GEUS database) with the velocities obtained from the modeling of the seismic refraction data along line 600 .

a general agreement between the two velocity curves but there are also deviations. For example, the velocity model has different velocity gradients within layers, since the refractions primarily constrain velocities at the top of each layer. The layer at a depth of $1500 \mathrm{~m}$ and a sonic velocity of $4.5 \mathrm{~km} / \mathrm{s}$ is completely missing in the velocity model because no refractions could be detected in the seismic data and, hence, such a layer is not required by the data. By missing this layer and having too low a velocity gradient in

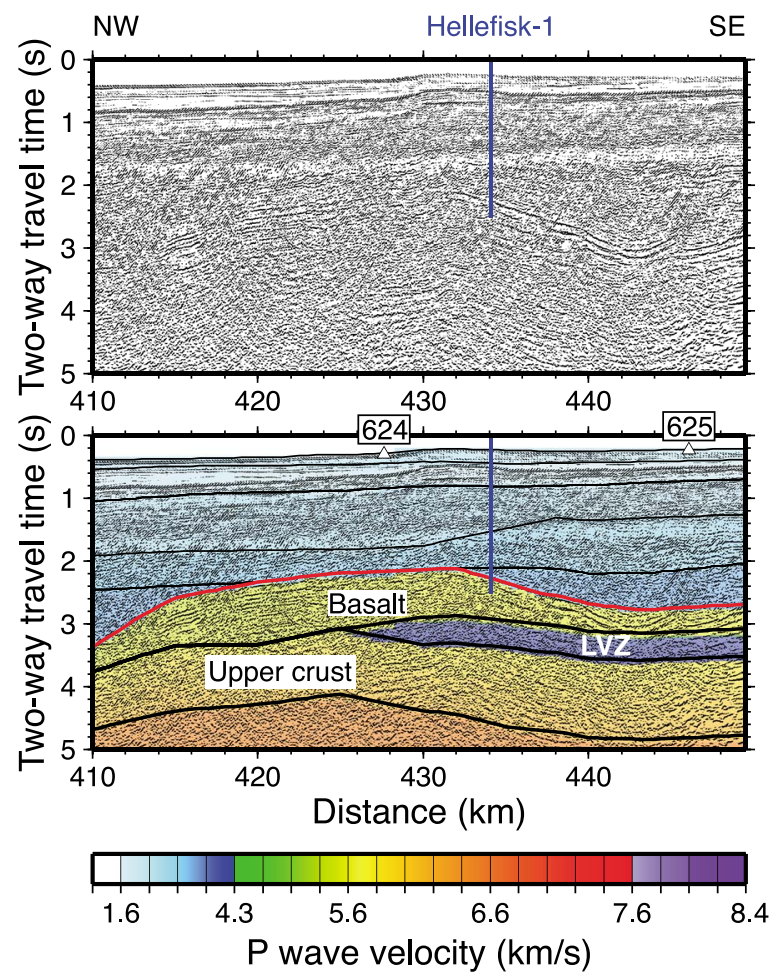

Figure 12. Part of seismic reflection record on line BGR08-315 around the Hellefisk-1 well. The well location is marked by a blue line. (top) Migrated seismic record, and (bottom) the same record shown together with velocity model (Figure 9) converted to two-way travel time. Triangles indicated the location of OBS 624 and 625. Abbreviation LVZ is low-velocity zone.

the underlying layer, the average velocity down to basement was underestimated. Thus, the top of the volcanic unit (velocities $>5 \mathrm{~km} / \mathrm{s}$ ) is modeled $400 \mathrm{~m}$ too deep. However, in two-way travel time, the velocity model still fits the travel time to the top of the volcanic layer as can be seen when compared with the coincident seismic reflection data (Figure 12). Velocities within the basalts compare fairly well (around $5.5 \mathrm{~km} / \mathrm{s}$ ). In summary, the comparison shows that the refraction data are unable to resolve the detailed velocity structure within the sediments but still match the long-wavelength features. It can also be seen that the absolute depth error of layer boundaries at the basement level is on the order of 400 to $500 \mathrm{~m}$.

\subsection{Gravity Modeling}

[38] Gravity modeling can provide additional constraints on velocity models, in particular in areas where the

Figure 10. Ray coverage along line 600 obtained from "point to point" (shot to OBS) ray-tracing for all travel time picks used for the modeling (only phases below basement are shown). The figure is divided into four panels for different depth levels. The lower part of each panel shows the layer boundaries of the velocity model together with the raypaths; the upper part visualizes the calculated travel times (solid lines) and the associated travel time picks (vertical bars with a height corresponding to the estimated pick uncertainty). Not every travel time pick and ray is plotted, a distance of $2 \mathrm{~km}$ between picks is used to keep the plot readable. Triangles mark the positions of the OBS's. For phase names see also Table 1. Abbreviations are HVZ, high-velocity zone; L2, oceanic layer 2; L3, oceanic layer 3; LC, lower crust; MC, mid-crustal layer; UC, upper crust. 

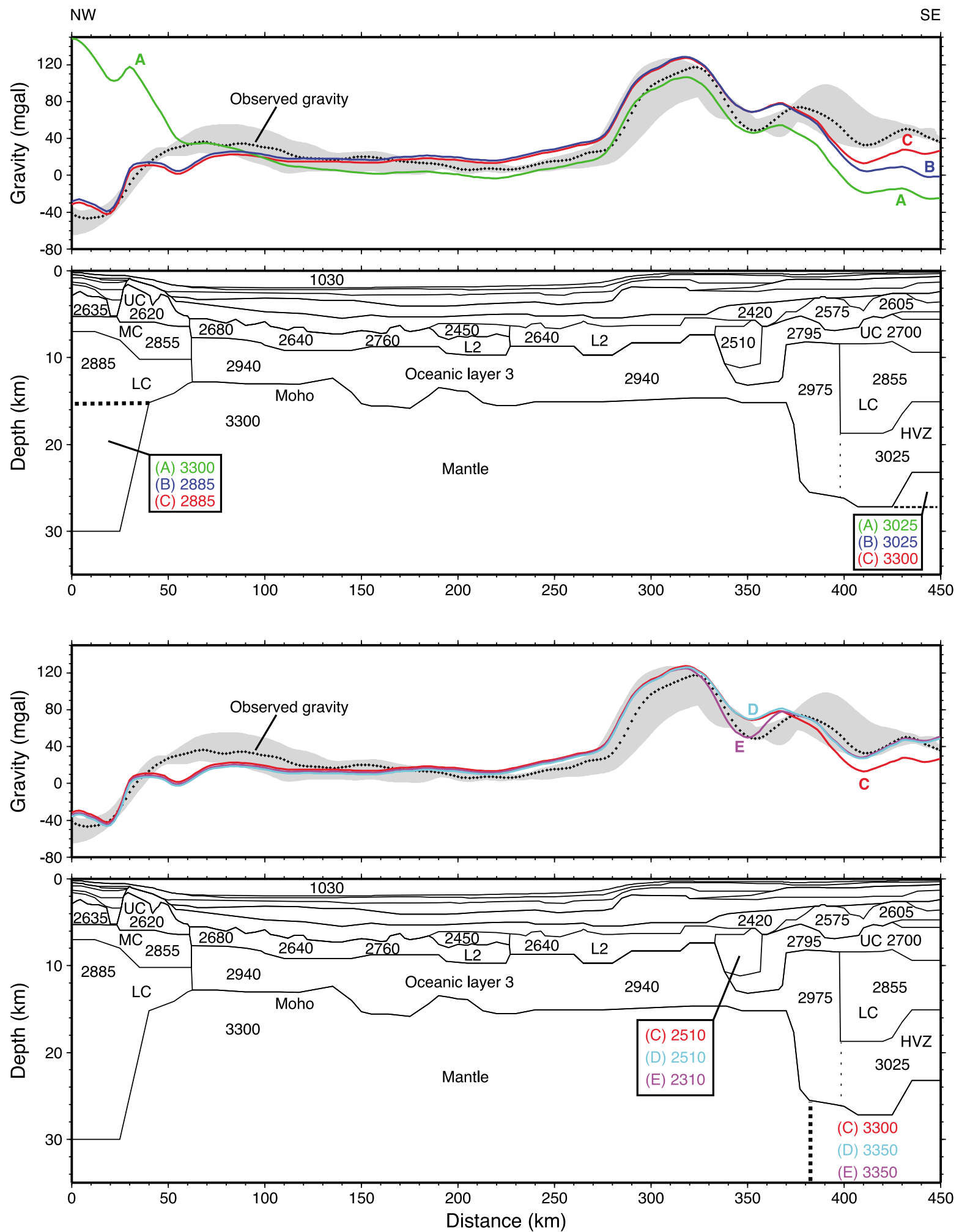

Figure 13. Gravity modeling along line 600. (top) Models A through C explore the Moho geometry at the outer limits of the model with no constraints from the seismic refraction data (compare with raycoverage in Figure 10). (bottom) Models A, D and $\mathrm{E}$ test for lateral variations of the density in the mantle and within the basin around $350 \mathrm{~km}$. The observed gravity is the free-air gravity measured during the MSM09/3 expedition. The shaded area indicates the range of gravity values in a $20-\mathrm{km}$-wide zone to either side of line 600 (extracted from DTU10 1-min grid [Andersen, 2010]). All densities in the model are given in $\mathrm{kg} \mathrm{m}^{-3}$. For details see text. Abbreviations are HVZ, high-velocity zone; L2, oceanic layer 2; LC, lower crust; MC, mid-crustal layer; UC, upper crust. 


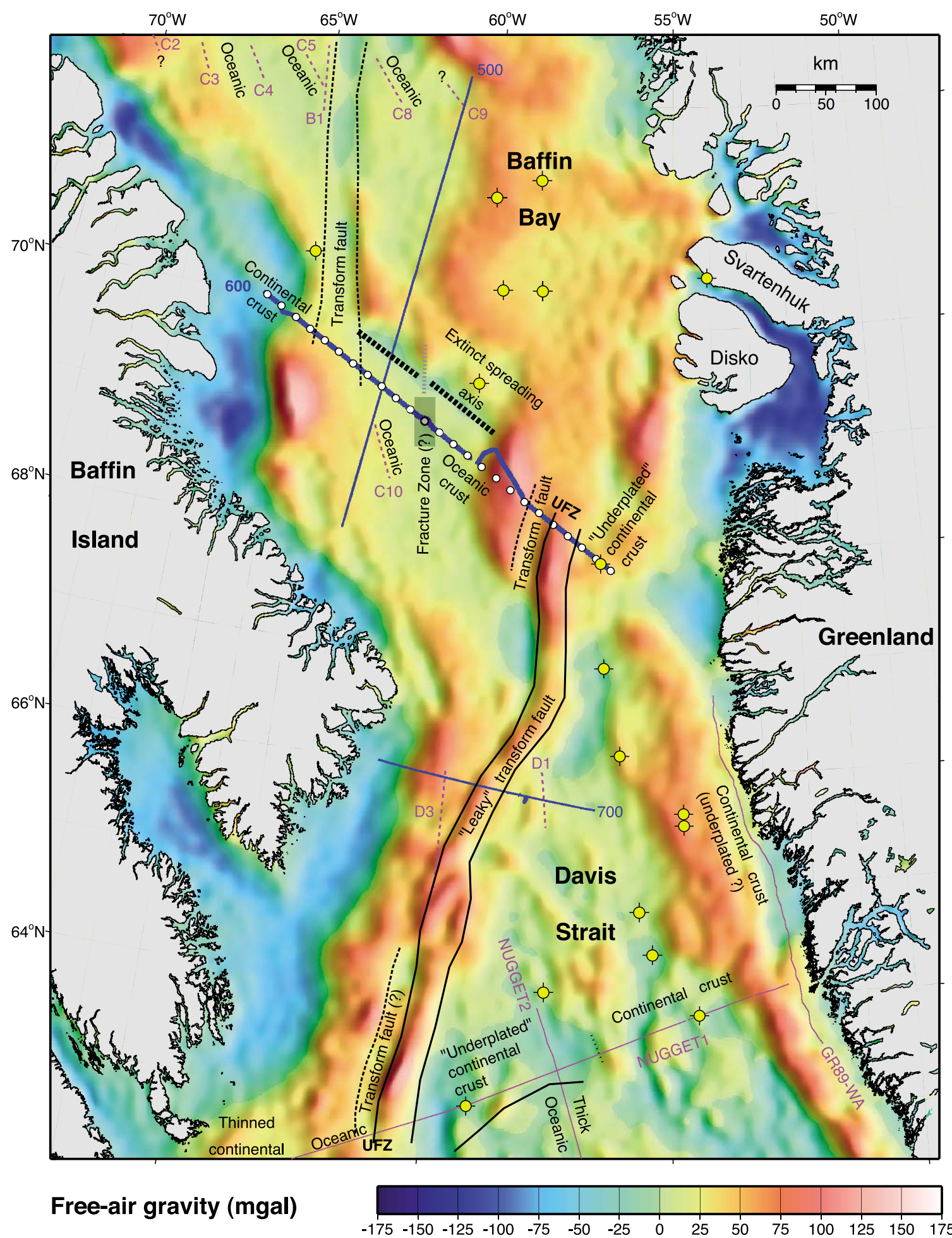

Figure 14. Free-air gravity map with interpretation of crustal character along line 600 and along other available seismic refraction lines. Shading by artificial illumination from the east. Data source: Satellite altimetry, DTU10 1-min grid [Andersen, 2010]. Blue lines refer to the MSM09/3 seismic refraction lines (AWI20080[500/600/700]) [Gohl et al., 2009]; pink lines show the location of other seismic refraction experiments: GR89-WA [Gohl and Smithson, 1993], NUGGET 1 [Funck et al., 2007], and NUGGET 2 [Gerlings et al., 2009]; dashed pink lines indicate sonobuoy experiments: $\mathrm{C} 1$ to $\mathrm{C} 10, \mathrm{~B} 1$ and $\mathrm{D} 1$ [Keen and Barrett, 1972], D3 [Srivastava et al., 1982]. The distribution of crustal domains and structural elements is indicated by black and gray lines. White circles mark the location of OBS on line 600. Yellow circles indicate the positions of wells (for well names compare with Figure 2). Abbreviation UFZ is Ungava fault zone. 
velocities are poorly resolved. In addition, gravity modeling can be used to verify how consistent the velocity model is with the gravity data. Gravity values are derived from the KSS31M sea gravimeter that was installed on the vessel Maria S. Merian. In this study, two-dimensional gravity modeling was performed along line 600 using the algorithm of Talwani et al. [1959]). The observed gravity in the models (Figure 13) are free-air gravity anomalies measured along the main line, i.e., not along the local deviation during the shooting. Densities were obtained from conversion of the $P$ wave velocities (Figure 9) using the curve shown by Ludwig et al. [1970], which is approximated by

$$
\rho=-2.83 v^{4}+70.4 v^{3}-598 v^{2}+2230 v-700
$$

where $\rho$ is the density in $\mathrm{kg} / \mathrm{m}^{3}$ and $v$ is the $P$ wave velocity in $\mathrm{km} / \mathrm{s}$. Densities of 1.03 and $3.30 \mathrm{~g} / \mathrm{cm}^{3}$ were used for the seawater and the mantle, respectively. There is no fixed reference gravity value. Instead, a reference is calculated from minimizing the misfit between observed and calculated gravity. Some caution has to be applied in the two-dimensional modeling approach as some gravity anomalies terminate very close to line 600 (Figure 14). Figure 13 illustrates that the gravity variations can be up to $70 \mathrm{mgal}$ in a $20-\mathrm{km}$-wide zone to either side of line 600 . Hence, the modeling and discussion focuses on general trends in the gravity data.

[39] In the starting model (Model A; Figure 13, top), the Moho is continued horizontally to the outer boundaries where there is no ray coverage. At the NW end of the line (between 0 and $40 \mathrm{~km}$ ) the Moho depth was kept at $15 \mathrm{~km}$. This depth is not compatible with the gravity data as the observed and calculated gravity deviate by up to $190 \mathrm{mgal}$. To compensate for that, the Moho depth was increased to $30 \mathrm{~km}$ at that end of the line (model B) and this resulted in a greatly reduced misfit. Full thickness continental crust beneath Baffin Island is likely to be $>30 \mathrm{~km}$ if one uses the measurements in the nearby Precambrian crust in northern Labrador as an indicator for the thickness [Funck and Louden, 1998, 1999; Funck et al., 2000a]. Receiver functions on southern Baffin Island also indicate a crustal thickness of $>40 \mathrm{~km}$ [Darbyshire, 2003]. However, the NW extension of line 600 runs for another $100 \mathrm{~km}$ on the shelf (Figure 2) where the crustal thickness is less than onshore.

[40] At the SE end of the line, a decrease of Moho depth by $4 \mathrm{~km}$ (model C) can reduce the misfit, although the calculated gravity is still too low. Further shallowing of the Moho in that area, however, started to affect the overall shape of the calculated gravity and was therefore not pursued. Instead, the mantle density was increased from 3300 to $3350 \mathrm{~kg} \mathrm{~m}^{-3}$ at the SE end of the line (model D; Figure 13, bottom), assuming that the lithosphere beneath the continental crust might be colder and denser than in the oceanic domain. However, this assumption is questionable as this zone is affected by the mantle plume as indicated by the HVZ beneath the continental crust that is interpreted as magmatic underplating. Decreasing the mantle density beneath the oceanic crust has a similar effect. This could be explained by high degrees of melting that strip out the magnesium and iron, which leaves a low-density restite behind. In any case, a lateral density change in the mantle greatly reduces the misfit between observed and calculated gravity in the southeast. Alternatively, a density increase in the HVZ can produce a similar effect as a lateral density variation within the mantle. When the density of the continental mantle beneath Baffin Island is increased to $3350 \mathrm{~kg} \mathrm{~m}^{-3}$ as well, the Moho there has to be adjusted to a depth of 31 to $32 \mathrm{~km}$ to keep the fit with the observed gravity. Between 70 and $110 \mathrm{~km}$, the pressure at the base of the model decreases by $10 \mathrm{MPa}$. This indicates some isostatic imbalance that is evidenced by the flat Moho in this zone while the basement shallows toward Baffin Island. This imbalance can be compensated for by a gradual landward increase of the density in the mantle. Such a lateral density increase would be compatible with a cooling of the lithosphere from the oceanic crust into the region that is interpreted as transform fault [Chalmers and Pulvertaft, 2001]. At the same time, such a density increase would reduce the misfit between observed and calculated gravity in this region.

[41] In a last modeling step, the misfit in the area of the basin at $340 \mathrm{~km}$ was investigated. As mentioned above, velocities within the basin are not well resolved and the velocity uncertainty may be up to 0.2 to $0.4 \mathrm{~km} / \mathrm{s}$. To obtain a good fit, the density had to be reduced from 2510 to $2310 \mathrm{~kg} \mathrm{~m}^{-3}$ (model E; Figure 13, bottom). Although this decreases the misfit in the area of the basin, it seems unlikely that the density within the basin is that low. A reduction by $200 \mathrm{~kg} \mathrm{~m}^{-3}$ compared to the empirical formula by Ludwig et al. [1970] corresponds to a velocity decrease from 4.8 to $3.1 \mathrm{~km} / \mathrm{s}$. This is far too low to explain the observed travel times in the seismic refraction data. In addition, both density and velocity would be lower than in the overlying sedimentary layers. Alternatively, the sedimentary basin could be deeper than the model indicates, as the seismic constraints on this are not very strong. However, the crust underneath the basin is already rather thin $(4 \mathrm{~km})$.

[42] In summary, even with some density adjustments, there is no perfect fit to the observed gravity data. Many of the deviations are likely due to three-dimensional effects that cannot be treated properly in a two-dimensional model. One example is the 4-km-deep sedimentary basin around $20 \mathrm{~km}$ (Figure 13) that is required to model the observed delays of crustal phases in that zone. The basin has a pronounced signature in the calculated gravity, but cannot be seen in the observed gravity. This indicates that the basin has to be a local feature that violates the assumption of two-dimensionality in the gravity model. Figure 14 shows a free-air gravity map of the study area. The map indicates that most features cross line 600 at an oblique angle. The most prominent departure from two-dimensionality occurs around the pronounced gravity high around OBS 621 . This high can be correlated southward all the way through the Davis Strait but disappears just to the north of the line.

\section{Discussion and Interpretation}

[43] In section 4.1, the model for line 600 was presented with a description of the velocity distribution in the sediments, the crust, and the mantle. In addition, a first interpretation of the crustal structure was given. However, a more thorough discussion of the model is necessary and is presented in this section. The model is discussed in context of the regional geology as well as compared to studies in similar tectonic and geologic settings. The discussion starts in 


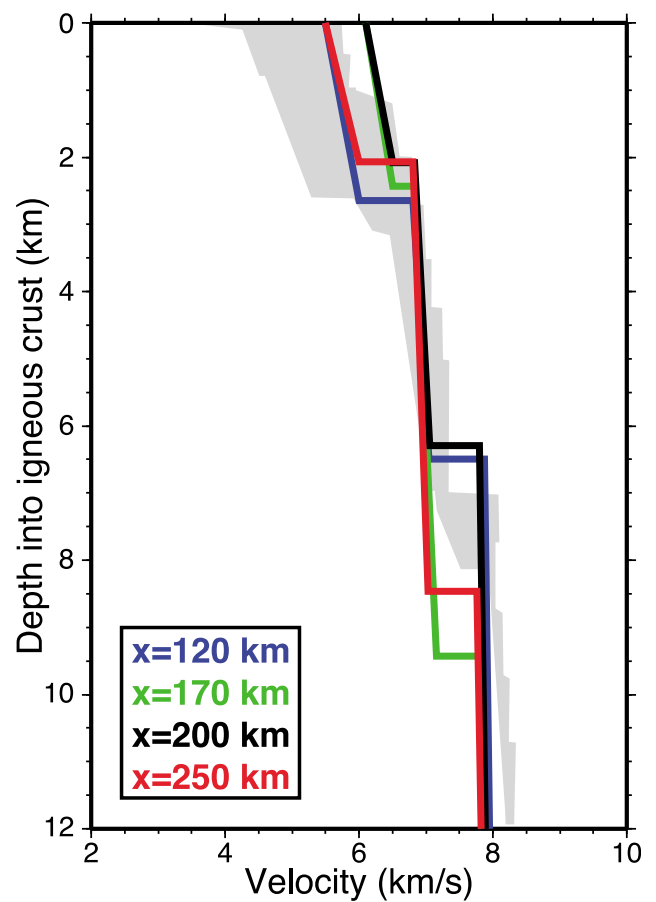

Figure 15. Comparison of velocity-depth functions from line 600 with average oceanic crust. The gray area shows the range of typical oceanic crust encountered in the Atlantic Ocean with a crustal age between 59 and $127 \mathrm{Ma}$ [White et al., 1992]. The color lines show the velocities from line 600 ; the position $(\mathrm{km})$ refers to the distance along the velocity model (Figure 9).

the NW of the profile off Baffin Island and then moves toward the SE following the segmentation of the crust indicated in Figure 9.

\subsection{Continental Crust (0-60 km)}

[44] The segment between 0 and $60 \mathrm{~km}$ is interpreted as continental crust (Figure 9). The velocity structure is divided into three layers with velocities that are not typical of oceanic crust [White et al., 1992]. In addition, the occurrence of mid-crustal reflections is a strong indicator for continental crust [Mooney and Brocher, 1987]. Velocities of 5.5 to 6.3 and 6.6 to $6.9 \mathrm{~km} / \mathrm{s}$ for the upper and lower crust, respectively, compare well with the range of velocities found elsewhere in West Greenland and Eastern Canada along the shores of the Labrador Sea and the Baffin Bay. For this comparison, the mid-crustal layer is considered as part of the upper crust. The Archean Nain Province in Labrador, where Funck and Louden [1998] report velocities of 5.8 to 6.5 and 6.6 to $6.9 \mathrm{~km} / \mathrm{s}$ in the upper and lower crust, respectively, is very close to the study area. In the Nain Province, the uppermost crust was interpreted to have a gneissic composition based on $P$ wave velocities and a Poisson's ratio of 0.20 to 0.24 . To the SE of Baffin Island along NUGGET line 1, upper and lower crustal velocities of 5.8 to 6.1 and 6.4 to $6.6 \mathrm{~km} / \mathrm{s}$ were reported [Funck et al., 2007]. However, upper crustal velocities there are only poorly resolved. Farther to the east on that line (off Greenland), upper crustal velocities were as low as $5.4 \mathrm{~km} / \mathrm{s}$. This is very close to the observed $5.5 \mathrm{~km} / \mathrm{s}$ on line 600. Funck et al. [2007] suggested a granitic composition of the upper crust on NUGGET line 1. Intense faulting on line 600 as indicated by the rough basement topography between 0 and $60 \mathrm{~km}$, may result in a reduction of the $P$ wave velocity. Laboratory measurements of rock samples measured at pressures compatible with midcrustal levels (300-500 MPa) indicate $P$ wave velocities of $6.07 \pm 0.22 \mathrm{~km} / \mathrm{s}$ for granite [Holbrook et al., 1992], which is higher than what is observed on line 600 . However, on a seismic refraction line off SW Greenland, Chian et al. [1995b] reported upper crustal velocities of $5.4 \mathrm{~km} / \mathrm{s}$ in an area that is characterized by widespread granitic intrusions.

[45] One other interesting aspect of the continental crust at the NW end of line 600 is the abrupt transition to oceanic crust at around $60 \mathrm{~km}$ (Figure 9), without any indication for a transitional crust. Transitional crust at non-volcanic continental margins is often characterized by velocities that differ from the adjacent normal continental and oceanic crust and that are often difficult to interpret. The lack of such a transition zone is interpreted to be related to the location of line 600, which is parallel to the assumed extinct spreading axis [Chalmers and Pulvertaft, 2001; Chalmers and Oakey, 2007] (Figure 2). The boundary from continental to oceanic crust crosses a N-S striking gravity low (Figure 14) that is interpreted as transform margin [Chalmers and Pulvertaft, 2001]. Crustal thinning across transform margins is characterized by a thinning of the crust over short distance. One well-studied transform margin is the margin off Ghana in the Equatorial Atlantic. Edwards et al. [1997] show that the continental crust thins from 23 to $4 \mathrm{~km}$ over a distance of only $20 \mathrm{~km}$ when initial oceanic crust is encountered. Such a thinning is comparable to the one observed on line 600, although it is only constrained by gravity modeling. Another example for rapid thinning of the continental crust with no transition zone can be found at the transform margin south of Svalbard [Breivik et al., 2003] or off South Africa where the transition occurs over a 50-km-wide zone [Parsiegla et al., 2009].

[46] The thickness of the continental crust at the transition to the oceanic crust is $7 \mathrm{~km}$ (Figure 9). This value is compatible with the $8 \mathrm{~km}$ found at the seaward limit of the Baffin Island crust on NUGGET line 1 [Funck et al., 2007]. There are no seismic refraction data on Baffin Island to determine the thickness of the unstretched crust. However, receiver functions indicate a crustal thickness between 40 and $45 \mathrm{~km}$ beneath southern Baffin Island [Darbyshire, 2003]. This would indicate a stretching factor of six.

\subsection{Oceanic Crust (60-333 km)}

[47] The zone between 60 and $333 \mathrm{~km}$ is interpreted as oceanic crust but displays both lateral thickness and velocity variations. Velocity variations are restricted to the upper crustal layer (oceanic layer 2). Figure 15 shows a comparison with average oceanic crust in the North Atlantic with a crustal age between 59 and $127 \mathrm{Ma}$ as compiled by White et al. [1992]. The comparison shows that the layer 2 velocities of 6.1 to $6.5 \mathrm{~km} / \mathrm{s}$ between 135 and $227 \mathrm{~km}$ are slightly higher than average. Otherwise the velocities fall well into the range of typical oceanic crust both in terms of the absolute velocities and velocity gradients. With respect to crustal thickness, the values on line 600 are typically $6 \mathrm{~km}$ or $9 \mathrm{~km}$, which are either slightly lower or slightly higher when 
compared with average crust. White et al. [1992] found a global average thickness of $7.1 \pm 0.8 \mathrm{~km}$.

[48] Figure 9 shows that the lateral velocity variations in layer 2 correlate with changes in the observed magnetic anomalies. The zone with the higher velocities (6.1$6.5 \mathrm{~km} / \mathrm{s}$ ) displays positive anomalies, while the lower velocities $(5.5-6.0 \mathrm{~km} / \mathrm{s})$ are generally associated with negative magnetic anomalies. Changes of magnetic polarity in oceanic crust mirror the reversals of the Earth's magnetic field over time and, hence, the lateral changes observed along line 600 could indicate that the segments of oceanic crust have a different age. However, there is currently no consensus that there are seafloor-spreading magnetic anomalies in Baffin Bay (Figure 16). Nevertheless, the positive magnetic anomalies between OBS 609 and 612 show up as a linear feature that is parallel with the spreading axis, which is itself parallel to line 600 . The location of the spreading axis is assumed to coincide with a gravity low [Whittaker et al., 1997] (Figure 14), which is seismically confirmed by Suckro et al. [2012]. If the magnetic anomaly between OBS 609 and 612 is indeed related to seafloorspreading, it may correspond to polarity chron $21 \mathrm{n}$ (45.3 to $47.2 \mathrm{Ma}$ ) as this was the last clear spreading anomaly in the Labrador Sea [Roest and Srivastava, 1989] and has a similar distance to the extinct spreading axis. The southwestern and northeastern limitation of the magnetic anomaly fits with the location of a transform fault and an assumed fracture zone (cf. Figure 14).

[49] On the free-air gravity map (Figure 14), the extinct spreading axis in Baffin Bay stands out as a gravity low parallel to line 600 . In addition, another gravity low can be seen that continues northward from the extinct spreading axis, roughly between OBS 604 and 608. This gravity low correlates with a proposed transform fault along which the spreading axis is displaced to the north [Chalmers and Oakey, 2007] (Figure 2). It is in this zone that the oceanic crustal thickness is reduced to $6 \mathrm{~km}$. A second zone with reduced crustal thickness is observed near OBS 612 (Figure 9). Northward of this zone, the spreading axis shows a minor displacement (Figure 14) interpreted as the location of a fracture zone [Chalmers and Oakey, 2007] (Figure 2). There is no clear signal in the gravity that would connect the displacement in the spreading axis with the zone of reduced crustal thickness on line 600. However, such a trend would be consistent with the northward orientation of the transform fault in the west and the UFZ in the east. Variations in the thickness of oceanic crust can have various reasons. In the study region, thickness variations may for example relate to the variable nature of volcanic activity in the Davis Strait region. The crust in transform faults and fracture zones is often anomalously thin and the observed velocities can deviate from normal oceanic crust [Detrick et al., 1993]. Detrick et al. [1993] show that the crust in North Atlantic fracture zones is frequently quite thin $(<1-2 \mathrm{~km}$ thick) and is characterized by low $P$ wave velocities and the absence of a normal seismic layer 3 . These anomalies are explained by a reduced magma supply at the end of spreading segments. In contrast, the velocity structure within the transform fault and the assumed fracture zone on line 600 is much closer to normal oceanic crust even though it is thinner than the local average. This probably relates to the influence of the Iceland plume that provided ample magma supply in southern Baffin
Bay. This extra magma supply generated the 9-km-thick oceanic crust along the line, some $2 \mathrm{~km}$ thicker than average oceanic crust. Although the thickness decreases by $3 \mathrm{~km}$ within the transform fault and the assumed fracture zone, the resulting thickness of $6 \mathrm{~km}$ is still close to normal oceanic crust.

[50] Storey et al. [1998] identified two main pulses of volcanism in West Greenland: one between 60.7 and $59.4 \mathrm{Ma}$ and one between 54.8 and 53.6 Ma. On line 600, the distance to the extinct spreading axis is only $40 \mathrm{~km}$ and an oceanic crustal thickness of $9 \mathrm{~km}$ is observed, indicating that the plume must have influenced the region well after 53.6 Ma to create the thicker than normal oceanic crust. While the age of the oceanic crust along line 600 is not known, some estimates can be made. Srivastava and Keen [1995], in an interpretation of a seismic reflection line across the extinct spreading axis in the Labrador Sea, assume a half-spreading rate of $3 \mathrm{~mm} / \mathrm{yr}$ between magnetic anomalies 18 and 13. At anomaly 13 ( $\sim 33 \mathrm{Ma})$, Greenland and North America are thought to have moved as a single plate. Under the assumption that these parameters are applicable to the Baffin Bay as well, a $40 \mathrm{~km}$ distance to the axis at a halfspreading rate of $3 \mathrm{~mm} / \mathrm{yr}$ would translate to 13 million years prior to the cessation of spreading. This yields an age estimate of $46 \mathrm{Ma}$ for the oceanic crust on line 600 , some 7 millions of years after the last main pulse of volcanism sampled onshore West Greenland.

[51] The area between 285 and $335 \mathrm{~km}$ is seismically poorly resolved due to the deviation from the line. However, the most convincing fit to the observed travel times was achieved with a velocity structure that is compatible with oceanic crust. This zone is within the area that Gregersen and Bidstrup [2008] define as the Aasiaat Basin and Aasiaat Structural Trend. Some deep reflections in this zone are interpreted to have an Early to mid-Cretaceous age [Gregersen and Bidstrup, 2008] but lack a direct well control. With that age, the sediments would post-date the initiation of seafloor spreading and the underlying basement should be of continental character. This would contradict our interpretation as oceanic crust. In contrast, G. Oakey and J. Chalmers (A new model for the Paleogene motion of Greenland relative to North America: Plate reconstructions of the Davis Strait and Nares Strait regions between Canada and Greenland, submitted to Journal of Geophysical Research, 2012) infer from plate reconstructions that the Aasiaat Basin is most likely underlain by Paleocene oceanic crust.

\subsection{Transition Zone (333-400 $\mathbf{~ k m ) ~}$}

[52] The region between 333 and $400 \mathrm{~km}$ is named transition zone because its seismic character is different from both the adjacent 9-km-thick oceanic crust to the NW and the continental crust to the SE (Figure 9). The transition zone is divided into two very distinct segments. The area that is labeled leaky transform fault is characterized by $20-\mathrm{km}$-thick igneous crust, while the basin to the NW is underlain by only 4-km-thick crust of unknown nature.

\subsubsection{Leaky Transform Fault}

[53] The 20-km-thick igneous crust between 375 and $400 \mathrm{~km}$ lies within the area referred to as Ungava fault zone (UFZ) - a transform fault system that links the spreading axis in the northern Labrador Sea to that in the southern Baffin 


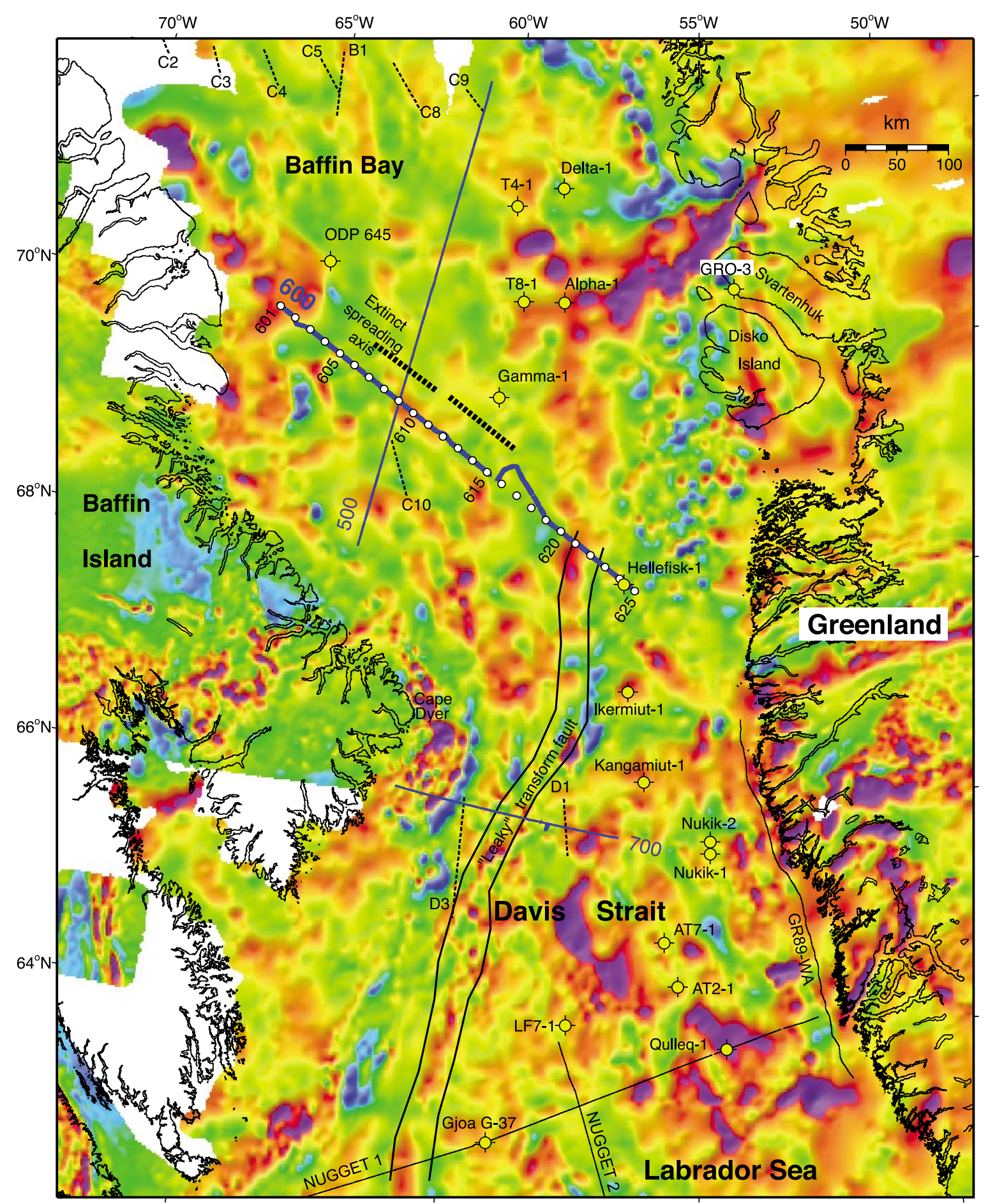

Magnetic anomalies (nT)

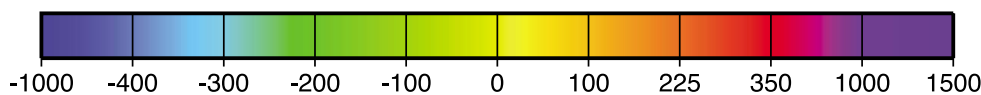

Figure 16. Magnetic anomaly map. Shading by artificial illumination from the southeast. Data source: Verhoef et al. [1996] and Oakey [2001]. Blue lines refer to the MSM09/3 seismic refraction lines (AWI20080[500/600/700]) [Gohl et al., 2009]; thin solid lines show the location of other seismic refraction experiments: GR89-WA [Gohl and Smithson, 1993], NUGGET 1 [Funck et al., 2007], and NUGGET 2 [Gerlings et al., 2009]; dashed lines indicate sonobuoy experiments: $\mathrm{C} 1$ to C10, B1 and D1 [Keen and Barrett, 1972], D3 [Srivastava et al., 1982]. The bold dashed lines indicate the location of the extinct spreading axis (taken from the gravity low shown in Figure 14). White circles mark the location of OBS on line 600 (every 5th station number is annotated). Yellow circles indicate the positions of wells. The outline of the leaky transform fault is taken from the gravity data (Figure 14). 


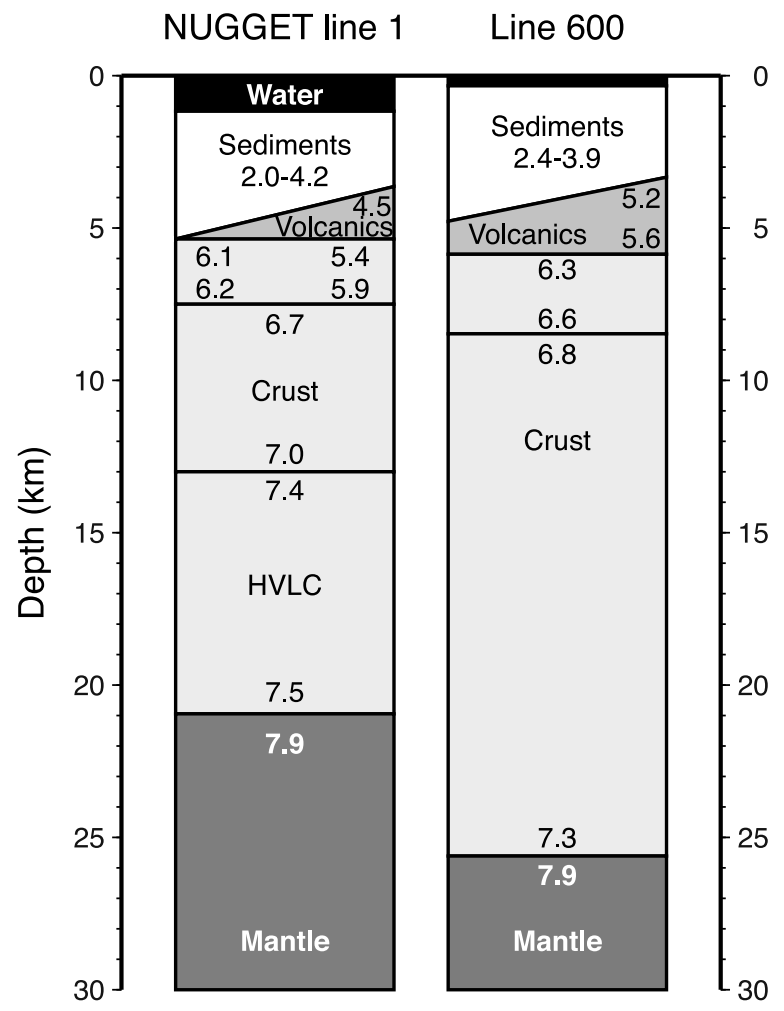

Figure 17. Comparison of velocity functions from within the Ungava fault zone. Simplified models from NUGGET line 1 (between 200 and $230 \mathrm{~km}$ ) [Funck et al., 2006] and line 600 (between 380 and $395 \mathrm{~km}$, this study). For location of the lines see Figure 1. Note that velocities below a depth of $12 \mathrm{~km}$ are not well resolved for this segment of line 600 . Abbreviation HVLC is high-velocity lower crust.

Bay. Storey et al. [1998] suggested that the Davis Strait went through transtensional phases that created gaps between the Canadian and Greenlandic continental crust. These gaps were then filled with melt that formed thick igneous crust. In this sense the UFZ acted as a leaky transform fault. Storey et al. [1998] link the Early Eocene volcanism in West Greenland to net extension on the UFZ, caused by a change in plate kinematics as the North Atlantic opened at $\sim 55$ Ma. Funck et al. [2007] identified 16-km-thick igneous crust within the UFZ in southern Davis Strait on NUGGET Line 1. They favor a Paleocene age of the UFZ based on radiometric dates of the basalts $(59.5 \mathrm{Ma})$ [Williamson et al., 2001] in the nearby Gjoa G-37 well.

[54] The igneous crust within the UFZ correlates with a gravity high that can be correlated through the entire Davis Strait (Figures 14). With the addition of this study, the oceanic or igneous character of this gravity high is confirmed at both ends (line 600 and NUGGET line 1) and there can be little doubt that this feature is composed of igneous crust along its entire length. In addition, the UFZ stands out as a prominent feature on the magnetic map (Figure 16), although the correlation is not as good as in the gravity data. In particular, the northern part of the UFZ appears less continuous in the magnetic data.

[55] Comparison of the velocity models of the UFZ in the north (line 600) and in the south (NUGGET line 1) indicates some lateral changes (Figure 17). In general, the crustal velocities on these two lines are very similar and any differences are close to the limit of seismic resolution. More significant seems to be the division into a distinct HVZ on NUGGET line 1 that is overlain by two crustal layers that are similar to normal oceanic crust with a total thickness of $8 \mathrm{~km}$. The distinct HVZ could indicate a multiphase development. First, transtension or extension between Greenland and Canada produced a gap that was filled with new igneous crust with a velocity structure similar to normal oceanic crust. Afterwards, this new crust, as well as the adjacent thinned continental crust, was magmatically underplated, creating the HVZ. This magmatic underplating is consistent with geodynamic models [e.g., Nielsen et al., 2002] that suggest southward flow of plume material through Davis Strait along lithospheric thin spots. In the north, no such division into an upper and lower unit could be detected. However, the zone where thick igneous crust is observed is much narrower on line 600 than on NUGGET line $1(30 \mathrm{~km}$ versus $60 \mathrm{~km}$ width). The detection of a potentially weak reflection within the igneous crust from the top of a HVZ would be significantly more difficult in such a narrow zone. The thickness decrease of the igneous crust from north to south seems to be compatible with the previously mentioned southward channelling of plume material through Davis Strait. Including the overlying basalts, the igneous thickness is $23 \mathrm{~km}$ in the north compared to $17 \mathrm{~km}$ in the south. The volcanism also extends into the Baffin Bay, where widespread Paleogene basalts are observed off Disko and Svartenhuk (Figure 2). A volcanic margin extends as far north as the northern end of line 500 where there is indication for a high-velocity lower crustal layer [Suckro et al., 2012].

\subsubsection{Basin/Transform Fault}

[56] Between 333 and $357 \mathrm{~km}$, the velocity model (Figure 9) indicates the presence of a 5-km-deep basin. As discussed earlier, velocities within the basin are poorly resolved but are probably within $\pm 0.2 \mathrm{~km} / \mathrm{s}$ of the modeled 4.7 to $4.9 \mathrm{~km} / \mathrm{s}$. The crust immediately below the basin was not sampled by refracted waves and, hence, the velocities are unknown.

[57] There are two possible explanations for the basin. Either this segment is a thin sliver of stranded continental crust left between the leaky transform fault and the oceanic crust or it is a transform fault, possibly associated with the UFZ. If the basin is located on continental crust, the infill could contain Cretaceous or older sediments. However, as the igneous crust of the leaky transform fault can be correlated directly to the SE flank of the basin, it appears more likely that the bulk of the infill consists of volcanic material, possibly interbedded with some non-volcanic sediments. The velocities of 4.7 to $4.9 \mathrm{~km} / \mathrm{s}$ can be easily explained with volcanic rocks. Sonic log measurements in the Lopra-1 borehole on the Faroe Islands show velocities between 3.3 and $6.6 \mathrm{~km} / \mathrm{s}$ in the volcanic sequence, which consists of basalts and hyaloclastites [Christie et al., 2006].

[58] On the free-air gravity map (Figure 14), the basin shows up as a north-south striking linear feature bordered by two gravity highs. The western gravity high (around OBS 618 or at $320 \mathrm{~km}$ in Figure 13) follows the shelf break northward into the Baffin Bay with a variable amplitude. Watts [1988] note that such a free-air gravity high near the 
continental shelf break is typical for Atlantic continental margins.

[59] Seafloor spreading in a north-south direction requires a transform fault between the oceanic crust in the southernmost Baffin Bay and the continental crust observed at the SE end of line 600 . Based on the gravity signature, the leaky transform fault disappears just to the north of line 600 (Figure 14). Hence, the basin could easily form this transform fault if extended northward up to the extinct spreading axis. The interpretation as a transform fault can also explain the low crustal thickness of $4 \mathrm{~km}$ as is commonly observed in fracture zones and transform faults and discussed above [Detrick et al., 1993]. In this context it is interesting to note that a similar basin was observed on NUGGET line 1, where the leaky transform fault (UFZ) is bounded by a graben structure to the west [Funck et al., 2007]. Although the velocity structure within the graben is not very well resolved, the model for NUGGET line 1 indicates a volcanic fill (velocities of $5.4 \mathrm{~km} / \mathrm{s}$ ) and the crust is potentially only 3 to $4 \mathrm{~km}$ thick (not including the underlying $\mathrm{HVZ}$ ) [Funck et al., 2007]. However, the 5.4-km/s layer could also represent oceanic layer 2 , in which case the crust would be $7 \mathrm{~km}$ thick; but still thinner than the crust within the UFZ. In summary, the UFZ seems to be bounded by a narrow zone with thinned crust to the west. However, more work is needed to determine if this feature is continuous through Davis Strait.

\subsection{Underplated Continental Crust (400-450 km)}

[60] Finally, the continental crust at the SE end of line 600 is discussed. Velocities in the upper and lower crust between 400 and $450 \mathrm{~km}$ are well-resolved (Figure 9) and are very distinct from the oceanic and igneous crust observed elsewhere along the line. Hence, there is little doubt that this crust has a continental character with velocities of 5.9 to $6.2 \mathrm{~km} / \mathrm{s}$ and 6.5 to $6.8 \mathrm{~km} / \mathrm{s}$ in the upper and lower layer, respectively. Further evidence for a continental affinity comes from the observed mid-crustal reflections. While the lower crustal velocities are comparable to the ones found off Baffin Island, upper crustal velocities off Greenland are slightly lower than off Baffin Island. However, the NW and $\mathrm{SE}$ ends of line 600 are not conjugate. In a plate reconstruction [Skaarup et al., 2006], the SE end of line 600 would move southward to a position some 100 to $200 \mathrm{~km}$ to the north of NUGGET line 1 (for location see Figure 1). Hence, the Baffin Island continental crust on NUGGET line 1 would come close to the continental crust off Greenland on line 600. Indeed, velocities on NUGGET line 1 are 5.8 to $6.1 \mathrm{~km} / \mathrm{s}$ and 6.4 to $6.6 \mathrm{~km} / \mathrm{s}$ in the upper and lower crust, respectively [Funck et al., 2007], close to the values found off Greenland on line 600 (Figure 9).

[61] The crust at the SE end of line 600 has a continental affinity but was later modified by the Iceland plume that created the basaltic layer at the top (as drilled in the Hellefisk-1 well) and the HVZ at the base of the crust. The HVZ is interpreted as magmatic underplating. A similar layer is observed on NUGGET line 1 beneath the thinned portions of the continental crust but disappears to the east where the Greenlandic continental crust thickens [Funck et al., 2007]. This observation was interpreted by Funck et al. [2007] to be consistent with the channelling model of Sleep [1997] and Nielsen et al. [2002]. In this model, buoyant plume material ponds at the base of the lithosphere and then flows laterally and preferentially along thin lithosphere. With a thickness between 9 and $13 \mathrm{~km}$ (not including the volcanics and the HVZ), the continental crust around the Hellefisk-1 well can be considered as thinned when compared with full-thickness continental crust in this area. Gohl and Smithson [1993] report a thickness of up to $40 \mathrm{~km}$ on a line in Davis Strait close to the coast of Greenland (for location see Figure 14).

\section{Conclusions}

[62] The data from line 600 provide new insight into the crustal affinity and geodynamic evolution in the southern Baffin Bay. The central part of the line is characterized by oceanic crust that is divided into several segments based on crustal thickness and on velocities within layer 2 (Figure 9). In the NW near Baffin Island, the line crosses a transform margin with a sharp transition from continental into oceanic crust. The oceanic crust at this transition is 6 to $7-\mathrm{km}$ thick, which is approximately the same as normal oceanic crust (7 km) [White et al., 1992]. However, it is thinner than along most of the remainder of the line. Thus, the segment is interpreted to be part of the transform fault that can be correlated northward in the gravity data (Figure 14). An offset in the extinct spreading axis correlates with another segment of thinned oceanic crust $(6 \mathrm{~km})$ that is assumed to lie within an oceanic fracture zone. Similar to the transform fault in the west, this assumed fracture zone cuts the spreading axis at an oblique angle, which is further confirmation for oblique seafloor spreading in Baffin Bay as suggested by Chalmers and Pulvertaft [2001].

[63] A third zone with a reduced crustal thickness $(4 \mathrm{~km})$ is interpreted as a transform fault with a probable oceanic composition that separates oceanic crust in the southern Baffin Bay from 20-km-thick igneous crust and continental crust farther landward. The igneous crust coincides with a gravity high that can be correlated through the Davis Strait and into the Labrador Sea, where similar igneous crust is observed on NUGGET line 1 [Funck et al., 2007]. This igneous crust is thought to form a leaky transform fault (Ungava fault zone) where material from the Paleogene Iceland plume filled the gaps that developed during phases of transtension. The plume also created the high-velocity zone beneath the continental crust on the Greenland side of the line. Based on its distance to the extinct spreading axis $(40 \mathrm{~km})$, the oceanic crust on line 600 may have an approximate age of $46 \mathrm{Ma}$. Given that the oceanic crust here is thicker than the global average $(9 \mathrm{~km}$ outside the fracture zones and transform faults compared to $7 \mathrm{~km}$ for typical or average crust), the plume seems to have influenced the spreading system for a long time after the initial impact of the plume. This impact is thought to coincide with the first major volcanic pulse in West Greenland at around 60.7 to $59.4 \mathrm{Ma}$ [Storey et al., 1998]. The thicker than normal oceanic crust in the southern Baffin Bay is in contrast to northern Baffin Bay, where Reid and Jackson [1997] find serpentinized mantle indicative of a low magma supply. Hence, somewhere in Baffin Bay, a transition from volcanic to non-volcanic continental margins is expected. This would be similar to what is observed in the Labrador Sea [Keen et al., 2012]. 
[64] The continental crust at the SE end of the line is overlain by volcanic rocks that were drilled in the Hellefisk-1 well. The velocity model indicates a maximum thickness of $4 \mathrm{~km}$ for the basalts. A low-velocity zone observed beneath some of these basalts may indicate the presence of older sediments deposited prior to the Paleocene volcanics. However, as there are no velocity constraints at all for this LVZ, the layer may also represent basalts with a lower velocity.

[65] Acknowledgments. We thank all personnel onboard the RV Maria S. Merian who helped to collect the seismic data. We are grateful to Jim Chalmers and Gordon Oakey who made their geological map available in digital format. John Hopper read an earlier version of the manuscript. Reviews by Charlotte Keen, Keith Louden, and the Associate Editor greatly improved the manuscript. Funding for the cruise was provided by Deutsche Forschungsgemeinschaft. Various parts of the project were funded by AWI, BGR, and GEUS with support by the Danish National Research Council. IfM-Geomar provided ocean bottom seismometers through an EU grant (contract RITA-CT-2004-505322). Support for the data analysis was provided by Capricorn Greenland, Dong E\&P Grønland A/S, ExxonMobil, and Husky Energy. The paper is published with the permission of the Geological Survey of Denmark and Greenland.

\section{References}

Andersen, O. B. (2010), The DTU10 Gravity field and Mean sea surface, paper presented at Second International Symposium of the Gravity Field of the Earth (IGFS2), Univ. of Alaska Fairbanks, Fairbanks.

Breivik, A. J., R. Mjelde, P. Grogan, H. Shimamura, Y. Murai, and Y. Nishimura (2003), Crustal structure and transform margin development south of Svalbard based on ocean bottom seismometer data, Tectonophysics, 369, 37-70, doi:10.1016/S0040-1951(03)00131-8.

Chalmers, J. A. (1997), The continental margin off southern Greenland: Along-strike transition from an amagmatic to a volcanic margin, J. Geol. Soc., 154, 571-576, doi:10.1144/gsjgs.154.3.0571.

Chalmers, J. A., and K. H. Laursen (1995), Labrador Sea: The extent of continental and oceanic crust and the timing of the onset of seafloor spreading, Mar. Pet. Geol., 12, 205-217, doi:10.1016/0264-8172(95) 92840-S

Chalmers, J. A., and G. N. Oakey (2007), Cretaceous-Palaeogene development of Labrador Sea and Davis Strait, Geophys. Res. Abstr., 9, 01638.

Chalmers, J. A., and T. C. R. Pulvertaft (2001), Development of the continental margins of the Labrador Sea: A review, in Non-Volcanic Rifting of Continental Margins: A Comparison of Evidence From Land and Sea, edited by R. C. L. Wilson et al., Geol. Soc. Spec. Publ., 187, 77-105, doi:10.1144/GSL.SP.2001.187.01.05

Chian, D., and K. E. Louden (1994), The continent-ocean crustal transition across the southwest Greenland margin, J. Geophys. Res., 99, 9117-9135, doi:10.1029/93JB03404.

Chian, D., C. Keen, I. Reid, and K. E. Louden (1995a), Evolution of nonvolcanic rifted margins: New results from the conjugate margins of the Labrador Sea, Geology, 23, 589-592, doi:10.1130/0091-7613(1995) $023<0589$ :EONRMN>2.3.CO;2.

Chian, D., K. E. Louden, and I. Reid (1995b), Crustal structure of the Labrador Sea conjugate margin and implications for the formation of nonvolcanic continental margins, J. Geophys. Res., 100, 24,239-24,253, doi:10.1029/95JB02162

Christie, P., I. Gollifer, and D. Cowper (2006), Borehole seismic studies of a volcanic succession from the Lopra-1/1A borehole in the Faroe Islands, northern North Atlantic, Geol. Surv. Den. Greenl. Bull., 9, 23-40.

Darbyshire, F. A. (2003), Crustal structure across the Canadian High Arctic region from teleseismic receiver function analysis, Geophys. J. Int., 152, 372-391, doi:10.1046/j.1365-246X.2003.01840.x.

Detrick, R. S., R. S. White, and G. M. Purdy (1993), Crustal structure of North Atlantic fracture zones, Rev. Geophys., 31, 439-458, doi:10.1029/ 93RG01952.

Edwards, R. A., R. B. Whitmarsh, and R. A. Scrutton (1997), The crustal structure across the transform continental margin off Ghana, eastern equatorial Atlantic, J. Geophys. Res., 102, 747-772, doi:10.1029/96JB02098.

Funck, T., and K. E. Louden (1998), Wide-angle seismic imaging of pristine Archean crust in the Nain Province, Labrador, Can. J. Earth Sci., 35, 672-685, doi:10.1139/e98-019.

Funck, T., and K. E. Louden (1999), Wide-angle seismic transect across the Torngat Orogen, northern Labrador: Evidence for a Proterozoic crustal root, J. Geophys. Res., 104, 7463-7480, doi:10.1029/1999JB900010.
Funck, T., K. E. Louden, R. J. Wardle, J. Hall, J. W. Hobro, M. H. Salisbury, and A. Muzzatti (2000a), Three-dimensional structure of the Torngat Orogen (NE Canada) from active seismic tomography, J. Geophys. Res., 105, 23,403-23,420, doi:10.1029/2000JB900228.

Funck, T., K. E. Louden, and I. D. Reid (2000b), Wide-angle seismic imaging of a Mesoproterozoic anorthosite complex: The Nain Plutonic Suite in Labrador, Canada, J. Geophys. Res., 105, 25,693-25,707, doi:10.1029/ 2000JB900237.

Funck, T., J. R. Hopper, H. C. Larsen, K. E. Louden, B. E. Tucholke, and W. S. Holbrook (2003), Crustal structure of the ocean-continent transition at Flemish Cap: Seismic refraction results, J. Geophys. Res., 108(B11), 2531, doi:10.1029/2003JB002434.

Funck, T., H. R. Jackson, K. E. Louden, S. A. Dehler, and Y. Wu (2004), Crustal structure of the northern Nova Scotia rifted continental margin (Eastern Canada), J. Geophys. Res., 109, B09102, doi:10.1029/ 2004JB003008.

Funck, T., H. R. Jackson, S. A. Dehler, and I. D. Reid (2006), A refraction seismic transect from Greenland to Ellesmere Island, Canada: The crustal structure in southern Nares Strait, Polarforschung, 74, 97-112.

Funck, T., H. R. Jackson, K. E. Louden, and F. Klingelhöfer (2007), Seismic study of the transform rifted margin in Davis Strait between Baffin Island (Canada) and Greenland: What happens when a plume meets a transform, J. Geophys. Res., 112, B04402, doi:10.1029/2006JB004308.

Gerlings, J., T. Funck, H. R. Jackson, K. E. Louden, and F. Klingelhöfer (2009), Seismic evidence for plume-derived volcanism of the continental margin in southern Davis Strait and northern Labrador Sea, Geophys. J. Int., 176, 980-994, doi:10.1111/j.1365-246X.2008.04021.x.

Gohl, K., and S. B. Smithson (1993), Structure of Archean crust and passive margin of southwest Greenland from seismic wide-angle data, J. Geophys. Res., 98, 6623-6638, doi:10.1029/93JB00016.

Gohl, K., B. Schreckenberger, and T. Funck (2009), The expedition of the research vessel "Maria S. Merian" to the Davis Strait and Baffin Bay in 2008(MSM09/3), Rep. Polar and Mar. Res. 587, 99 pp., Alfred Wegener Inst. for Polar and Mar. Res., Bremerhaven, Germany.

Gradstein, F. M., J. G. Ogg, and A. G. Smith (2005), A Geologic Time Scale 2004, 610 pp., Cambridge Univ. Press, Cambridge, U. K.

Gregersen, U., and T. Bidstrup (2008), Structures and hydrocarbon prospectivity in the northern Davis Strait area, offshore West Greenland, Petrol. Geosci., 14, 151-166, doi:10.1144/1354-079308-752.

Hall, J., K. E. Louden, T. Funck, and S. Deemer (2002), Geophysical characteristics of the continental crust along the Lithoprobe Eastern Canadian Shield Onshore-Offshore Transect (ECSOOT): A review, Can. J. Earth Sci., 39, 569-587, doi:10.1139/e02-005.

Holbrook, W. S., W. D. Mooney, and N. I. Christensen (1992), The seismic velocity structure of the deep continental crust, in Continental Lower Crust, edited by D. M. Fountain et al., pp. 1-43, Elsevier, New York.

Jackson, H. R., and I. Reid (1994), Crustal thickness variations between the Greenland and Ellesmere Island margins determined from seismic refraction, Can. J. Earth Sci., 31, 1407-1418, doi:10.1139/e94-124.

Jokat, W., O. Ritzmann, M. C. Schmidt-Aursch, S. Drachev, S. Gauger, and J. Snow (2003), Geophysical evidence for reduced melt production on the Arctic ultraslow Gakkel mid-ocean ridge, Nature, 423, 962-965, doi:10.1038/nature01706.

Keen, C. E., and D. L. Barrett (1972), Seismic refraction studies in Baffin Bay: An example of a developing ocean basin, Geophys. J. R. Astron. Soc., 30, 253-271, doi:10.1111/j.1365-246X.1972.tb05812.x.

Keen, C. E., M. J. Keen, D. J. Ross, and M. Lack (1974), Baffin Bay: Small ocean basin formed by sea-floor spreading, AAPG Bull., 58, 1089-1108.

Keen, C. E., K. Dickie, and S. A. Dehler (2012), The volcanic margins of the northern Labrador Sea: Insights to the rifting process, Tectonics, 31 , TC1011, doi:10.1029/2011TC002985.

Kerr, J. W. (1967), A submerged continental remnant of the Labrador Sea, Earth Planet. Sci. Lett., 2, 283-289, doi:10.1016/0012-821X(67)90143-4.

Klose, G. W., E. Malterre, N. J. McMillan, and C. G. Zinkan (1982), Petroleum exploration offshore southern Baffin Island, northern Labrador Sea, Canada, in Arctic Geology and Geophysics, edited by A. F. Embry and H. R. Balkwill, Mem. Can. Soc. Pet. Geol., 8, 233-244.

Larsen, H. C., and A. D. Saunders (1998), Tectonism and volcanism at the southeast Greenland rifted margin: A record of plume impact and later continental rupture, in Proc. Ocean Drill. Program Sci. Results, 152, 503-533.

Larsen, L. M., L. M. Heaman, R. A. Creaser, R. A. Duncan, R. Frei, and M. Hutchinson (2009), Tectonomagmatic events during stretching and basin formation in the Labrador Sea and the Davis Strait: Evidence from age and composition of Mesozoic to Palaeogene dyke swarms in West Greenland, J. Geol. Soc., 166, 999-1012, doi:10.1144/001676492009-038.

Lawver, L. A., and R. D. Müller (1994), Iceland hotspot track, Geology, 22, 311-314, doi:10.1130/0091-7613(1994)022<0311:IHT>2.3.CO;2 
Ludwig, W. J., J. E. Nafe, and C. L. Drake (1970), Seismic refraction, in The Sea, vol. 4, New Concepts of Sea Floor Evolution, Part I, edited by A. E. Maxwell, pp. 5-84, Wiley-Intersci., Hoboken, N. J.

Lutter, W. J., and R. L. Nowack (1990), Inversion for crustal structure using reflections from the PASSCAL Ouachita experiment, J. Geophys. Res., 95, 4633-4646, doi:10.1029/JB095iB04p04633.

Mooney, W. D., and T. M. Brocher (1987), Coincident seismic reflection/ refraction studies of the continental lithosphere: A global review, Rev. Geophys., 25, 723-742, doi:10.1029/RG025i004p00723.

Nielsen, T. K., H. C. Larsen, and J. R. Hopper (2002), Contrasting rifted margin styles south of Greenland: Implications for mantle plume dynamics, Earth Planet. Sci. Lett., 200, 271-286, doi:10.1016/S0012-821X(02) 00616-7.

Oakey, G. N. (2001), Magnetic anomaly, Davis Strait region, Canadian and Greenland Arctic, Open File Rep. 39358, Geol. Surv. of Can., Ottawa, Ont., Canada.

Parsiegla, N., J. Stankiewicz, K. Gohl, T. Ryberg, and G. UenzelmannNeben (2009), Southern African continental margin: Dynamic processes of a transform margin, Geochem. Geophys. Geosyst., 10, Q03007, doi:10.1029/2008GC002196.

Pearson, D. G., C. H. Emeleus, and S. P. Kelley (1996), Precise ${ }^{40} \mathrm{Ar} /{ }^{39} \mathrm{Ar}$ age for the initiation of Palaeogene volcanism in the Inner Hebrides and its regional significance, J. Geol. Soc., 153, 815-818, doi:10.1144/ gsjgs.153.6.0815

Reid, I., and H. R. Jackson (1997), Crustal structure of the northern Baffin Bay: Seismic refraction results and tectonic implications, J. Geophys. Res., 102, 523-542, doi:10.1029/96JB02656.

Roest, W. R., and S. P. Srivastava (1989), Sea-floor spreading in the Labrador Sea: A new re-construction, Geology, 17, 1000-1003, doi:10.1130/0091-7613(1989)017<1000:SFSITL>2.3.CO; 2 .

Rolle, F. (1985), Late Cretaceous-Tertiary sediments offshore central West Greenland: Lithostratigraphy, sedimentary evolution, and petroleum potential, Can. J. Earth Sci., 22, 1001-1019, doi:10.1139/e85-105.

Skaarup, N., H. R. H. H. Jackson, and G. Oakey (2006), Margin segmentation of Baffin Bay/Davis Strait, eastern Canada, based on seismic reflection and potential field data, Mar. Pet. Geol., 23, 127-144, doi:10.1016/j. marpetgeo.2005.06.002.

Sleep, N. H. (1997), Lateral flow and ponding of starting plume material, J. Geophys. Res., 102, 10,001-10,012, doi:10.1029/97JB00551.

Srivastava, S. P. (1978), Evolution of the Labrador Sea and its bearing on the early evolution of the North Atlantic, Geophys. J. R. Astron. Soc., 52, 313-357, doi:10.1111/j.1365-246X.1978.tb04235.x.

Srivastava, S. P., and C. E. Keen (1995), A deep seismic reflection profile across the extinct Mid-Labrador Sea spreading center, Tectonics, 14 372-389, doi:10.1029/94TC02453.

Srivastava, S. P., B. MacLean, R. F. Macnab, and H. R. Jackson (1982) Davis Strait: Structure and evolution as obtained from a systematic geophysical survey, in Arctic Geology and Geophysics, edited by A. F. Embry and H. R. Balkwill, Mem. Can. Soc. Pet. Geol., 8, 267-278.

Storey, M., R. A. Duncan, A. K. Pedersen, L. M. Larsen, and H. C. Larsen (1998), ${ }^{40} \mathrm{Ar} /{ }^{39} \mathrm{Ar}$ geochronology of the West Greenland Tertiary volcanic province, Earth Planet. Sci. Lett., 160, 569-586, doi:10.1016/ S0012-821X(98)00112-5

Suckro, S., et al. (2012), The crustal structure of southern Baffin Bay: Implications from a seismic refraction experiment, Geophys. J. Int., in press.

Talwani, M., J. L. Worzel, and M. Landisman (1959), Rapid gravity computations for two-dimensional bodies with application to the Mendocino submarine fracture zone, J. Geophys. Res., 64, 49-59, doi:10.1029/ JZ064i001p00049.

Verhoef, J., W. R. Roest, R. Macnab, and J. Arkani-Hamed, and the Members of the Project Team (1996), Magnetic anomalies of the Arctic and North Atlantic oceans and adjacent land areas, Open File Rep. 3125, Geol Surv. of Can., Ottawa, Ont., Canada.

Watts, A. B. (1988), Gravity anomalies, crustal structure and flexure of the lithosphere at the Baltimore Canyon Trough, Earth Planet. Sci. Lett., 89, 221-238, doi:10.1016/0012-821X(88)90174-4.

White, R. S., D. McKenzie, and K. O’Nions (1992), Oceanic crustal thickness from seismic measurements and rare earth element inversions, J. Geophys. Res., 97, 19,683-19,715, doi:10.1029/92JB01749.

Whittaker, R. C., N. E. Hamann, and T. C. R. Pulvertaft (1997), A new frontier province offshore northwest Greenland: Structure, basin development, and petroleum potential of the Melville Bay area, AAPG Bull., 81 , 978-998.

Williamson, M.-C., M. E. Villeneuve, L. M. Larsen, H. R. Jackson, G. N. Oakey, and B. Maclean (2001), Age and petrology of offshore basalts from the Southeast Baffin Island Shelf, Davis Strait, and the Western Greenland continental margin, paper presented at Joint Annual Meeting, Geol. and Mineral. Assoc. of Can., St. John's, Newfoundland, Canada.

Zelt, C. A., and D. A. Forsyth (1994), Modeling wide-angle seismic data for crustal structure: Southeastern Grenville Province, J. Geophys. Res., 99, 11,687-11,704, doi:10.1029/93JB02764.

Zelt, C. A., and R. B. Smith (1992), Seismic traveltime inversion for 2-D crustal velocity structure, Geophys. J. Int., 108, 16-34, doi:10.1111/ j.1365-246X.1992.tb00836.x.

V. Damm and I. Heyde, Federal Institute for Geosciences and Natural Resources, Stilleweg 2, D-30655 Hanover, Germany. (volkmar.damm@bgr. de; ingo.heyde@bgr.de)

T. Funck, Geological Survey of Denmark and Greenland, Øster Voldgade 10, DK-1350 Copenhagen, Denmark. (tf@geus.dk)

K. Gohl, Alfred Wegener Institute for Polar and Marine Research, Am Alten Hafen 26, D-27568 Bremerhaven, Germany. (karsten.gohl@awi.de) 